LA-13732-ENV

Environment

Approved for public release;

distribution is unlimited.

\title{
U.S. Department of Energy Report 1999 LANL Radionuclide Air Emissions
}

\section{Los Alamos}

NATIONAL LABORATORY

Los Alamos National Laboratory is operated by the University of California for the United States Department of Energy under contract W-7405-ENG-36. 
An Affirmative Action/Equal Opportunity Employer

This report was prepared as an account of work sponsored by an agency of the United States Government. Neither The Regents of the University of California, the United States Government nor any agency thereof, nor any of their employees, makes any warranty, express or implied, or assumes any legal liability or responsibility for the accuracy, completeness, or usefulness of any information, apparatus, product, or process disclosed, or represents that its use would not infringe privately owned rights. Reference herein to any specific commercial product, process, or service by trade name, trademark, manufacturer, or otherwise, does not necessarily constitute or imply its endorsement, recommendation, or favoring by The Regents of the University of California, the United States Government, or any agency thereof. The views and opinions of authors expressed herein do not necessarily state or reflect those of The Regents of the University of California, the United States Government, or any agency thereof. Los Alamos National Laboratory strongly supports academic freedom and a researcher's right to publish; as an institution, however, the Laboratory does not endorse the viewpoint of a publication or guarantee its technical correctness. 
U.S. Department of Energy Report 1999 LANL Radionuclide Air Emissions

Prepared by

Keith W. Jacobson 


\title{
U.S. Department of Energy Report 1999 LANL Radionuclide Air Emissions
}

\author{
Site Name: $\quad$ Los Alamos National Laboratory \\ Location: County of Los Alamos, New Mexico
}

Operations Office Information:

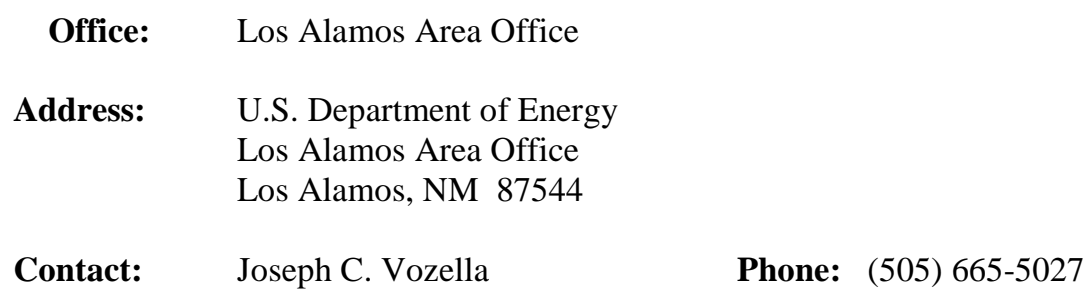

Site Information:
Operator: University of California
Address: $\quad$ Los Alamos National Laboratory
PO Box 1663
Los Alamos, NM 87545
Contact: Douglas M. Stavert
Phone: (505) 665-8855

Compliance Assessment:

1999 EDE: $\quad 0.32$ mrem 


\section{TABLE OF CONTENTS}

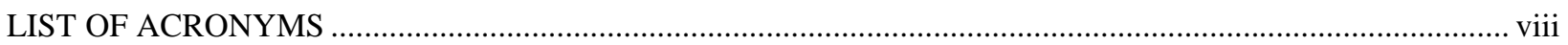

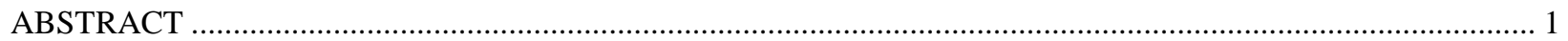

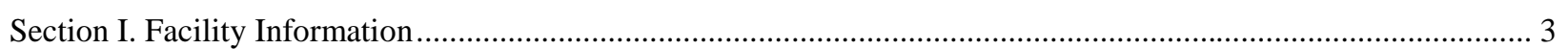

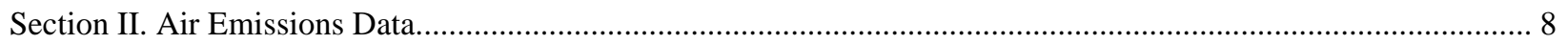

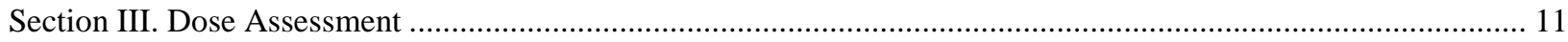

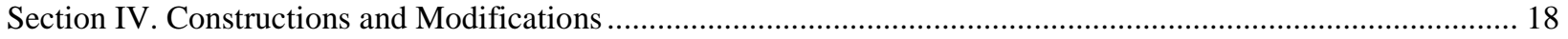

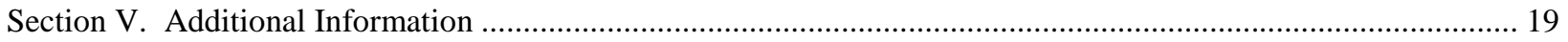

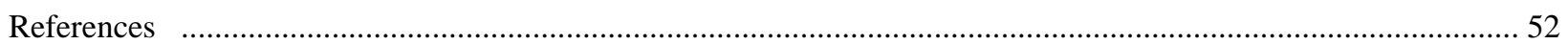

\section{TABLES}

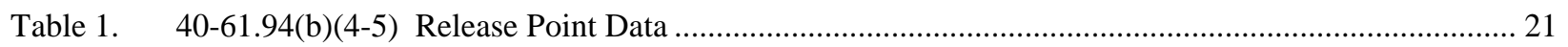

Table 2. 40-61.94(b)(6) Distances from Monitored Release Points to Nearest Receptor ................................... 25

Table 3. 40-61.94(b)(7) User-Supplied Data-Monitored Stack Parameters ..................................................... 26

Table 4. 69.94(b)(7) User-Supplied Data-Monitored Stack Parameters — $\mathrm{x}$ and y coordinates....................... 27

Table 5. 40-61.94(b)(7) User-Supplied Data-Highest Off-Site Dose Location for Monitored Release Points . 28

Table 6. 40-61.94(b)(7) User-Supplied Data-Other Input Parameters …………............................................ 29

Table 7. 40-61.94(b)(7) User-Supplied Data-Wind Frequency Arrays ………................................................. 30

Table 8. 40-61.94(b)(7) User-supplied Data-Population Array...................................................................... 38

Table 9. 40-61.94(b)(7) User-Supplied Data-Radionuclide Emissions .......................................................... 39

Table 10. 40-61.94(b)(7) User-Supplied Data-Modeling Parameters for LANL Non-Point Sources ................. 42

Table 11. 40-61.94(b)(7) User-Supplied Data—Radionuclides Not Included in CAP88 ….................................. 42

Table 12. 40-61.94(b)(7) User-Supplied Data—Supplemental Dose Factors ....................................................... 43

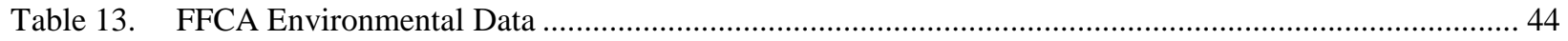

Table 14. FFCA Analytical Completeness Summary_Air Sampler Operation..................................................... 45

Table 15. LANSCE Monthly Assessments and Summary ............................................................................. 48

Table 16. 40-61.92 Effective Dose Equivalent at Selected Public Locations ....................................................... 49

Table 17. 40-61.92 Highest Effective Dose Equivalent Summary ……............................................................... 50

\section{FIGURES}

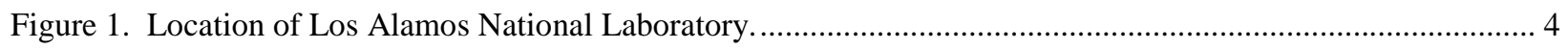

Figure 2. Los Alamos National Laboratory technical areas by number............................................................... 5

Figure 3. Locations of air sampling stations used for non-point source compliance............................................... 15

Figure 4. Locations in the Los Alamos townsite area evaluated for off-site dose .................................................. 17 
1999 LANL Radionuclide Air Emissions Report

\section{LIST OF ACRONYMS}

$\begin{array}{ll}\text { CAB } & \text { Citizens' Advisory Board } \\ \text { CMR } & \text { Chemistry and Metallurgy Research (building) } \\ \text { DOE } & \text { Department of Energy } \\ \text { EDE } & \text { effective dose equivalent } \\ \text { EPA } & \text { Environmental Protection Agency } \\ \text { ESIDNUM } & \text { exhaust stack identification number } \\ \text { FFCA } & \text { Federal Facilities Compliance Agreement } \\ \text { GMAP } & \text { gaseous mixed activation products } \\ \text { HEPA } & \text { high-efficiency particulate air (filter) } \\ \text { LANL } & \text { Los Alamos National Laboratory } \\ \text { LANSCE } & \text { Los Alamos Neutron Science Center } \\ \text { LSC } & \text { liquid scintillation counting } \\ \text { ND } & \text { no detectable (emissions) } \\ \text { PEDE } & \text { potential effective dose equivalent } \\ \text { P/VAP } & \text { particulate/vapor activation products } \\ \text { TA } & \text { technical area (at Los Alamos National Laboratory) } \\ & \end{array}$




\title{
U.S. Department of Energy Report 1999 LANL Radionuclide Air Emissions
}

\author{
Prepared by
}

Keith W. Jacobson

\begin{abstract}
Presented is the Laboratory-wide certified report regarding radioactive effluents released into the air by Los Alamos National Laboratory (LANL) in 1999. This information is required under the Clean Air Act and is being reported to the U.S. Environmental Protection Agency (EPA). The highest effective dose equivalent (EDE) to an off-site member of the public was calculated using procedures specified by the EPA and described in this report. For 1999, the dose was 0.32 mrem.
\end{abstract}




\section{Section I. Facility Information}

\subsection{4(b)(1) Name and Location of Facility}

Los Alamos National Laboratory (LANL or the Laboratory) and the associated residential areas of Los Alamos and White Rock are located in Los Alamos County, in north-central New Mexico, approximately 100 km (60 mi.) north-northeast of Albuquerque and 40 km (25 mi.) northwest of Santa Fe (Fig. 1).

\subsection{4(b)(2) List of Radioactive Materials Used at LANL}

Since the Laboratory's inception in 1943, its primary mission has been nuclear weapons research and development. Programs include weapons development, magnetic and inertial fusion, nuclear fission, nuclear safeguards and security, and laser isotope separation. There is also basic research in the areas of physics, chemistry, and engineering that supports such programs.

The primary facilities involved in emissions of radioactivity are outlined in this section. The facility locations are designated by technical area and building. For example, the facility designation TA-3-29 is Building 29 at Technical Area 3 (see Fig. 2 showing the technical areas at LANL). Potential radionuclide release points are listed in tables that follow. Some of the sources described below are characterized as non-point. Beginning in 1995, air sampling results from LANL's air sampling network (AIRNET) were used, with EPA approval, to calculate off-site impacts due to diffuse and fugitive emissions of radioactive particles and tritium oxide from non-point sources.

Radioactive materials used at LANL include weapons grade plutonium, heat source plutonium, enriched uranium, depleted uranium, and tritium. Also, a variety of materials are generated through the process of activation; consequent emissions occur as gaseous mixed activation products (GMAP), and other activation products occur in particulate and vapor form (P/VAP).

The radionuclides emitted from point sources at LANL in the calendar year (CY) 1999 are listed in the tables that follow this text. Tritium is released as tritium oxide and elemental tritium. Plutonium contains traces of Am241, a transformation product of $\mathrm{Pu}-241$. Some of the uranium emissions are from open-air explosive tests involving depleted uranium. GMAP emissions include Ar-41, C-10, C-11, N-13, N-16, O-14, and O-15. Various radionuclides such as Ga-68, Ge-68, Br-82, and Hg-197 make up the majority of the P/VAP emissions.

\subsection{4(b)(3) Handling and Processing of Radioactive Materials at LANL Technical Areas}

The primary facilities responsible for radiological airborne emissions follow. Additional descriptions of LANL technical areas can be found in the annual site environmental report for LANL.

TA-3-29: Programs conducting chemical and metallurgical research are located in this facility. Principal radionuclides are isotopes of plutonium and uranium. 
1999 LANL Radionuclide Air Emissions Report

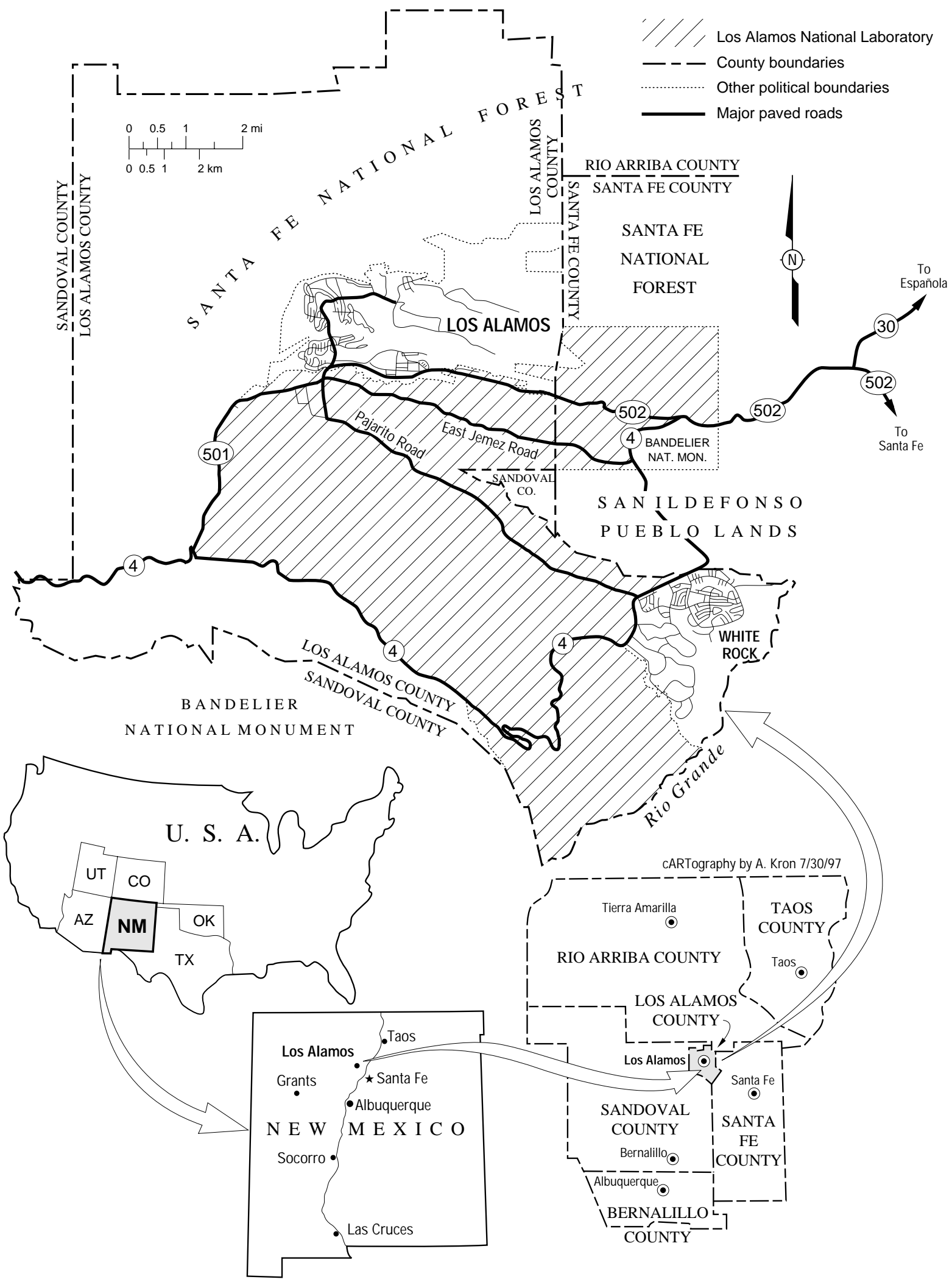

Figure 1. Location of Los Alamos National Laboratory. 


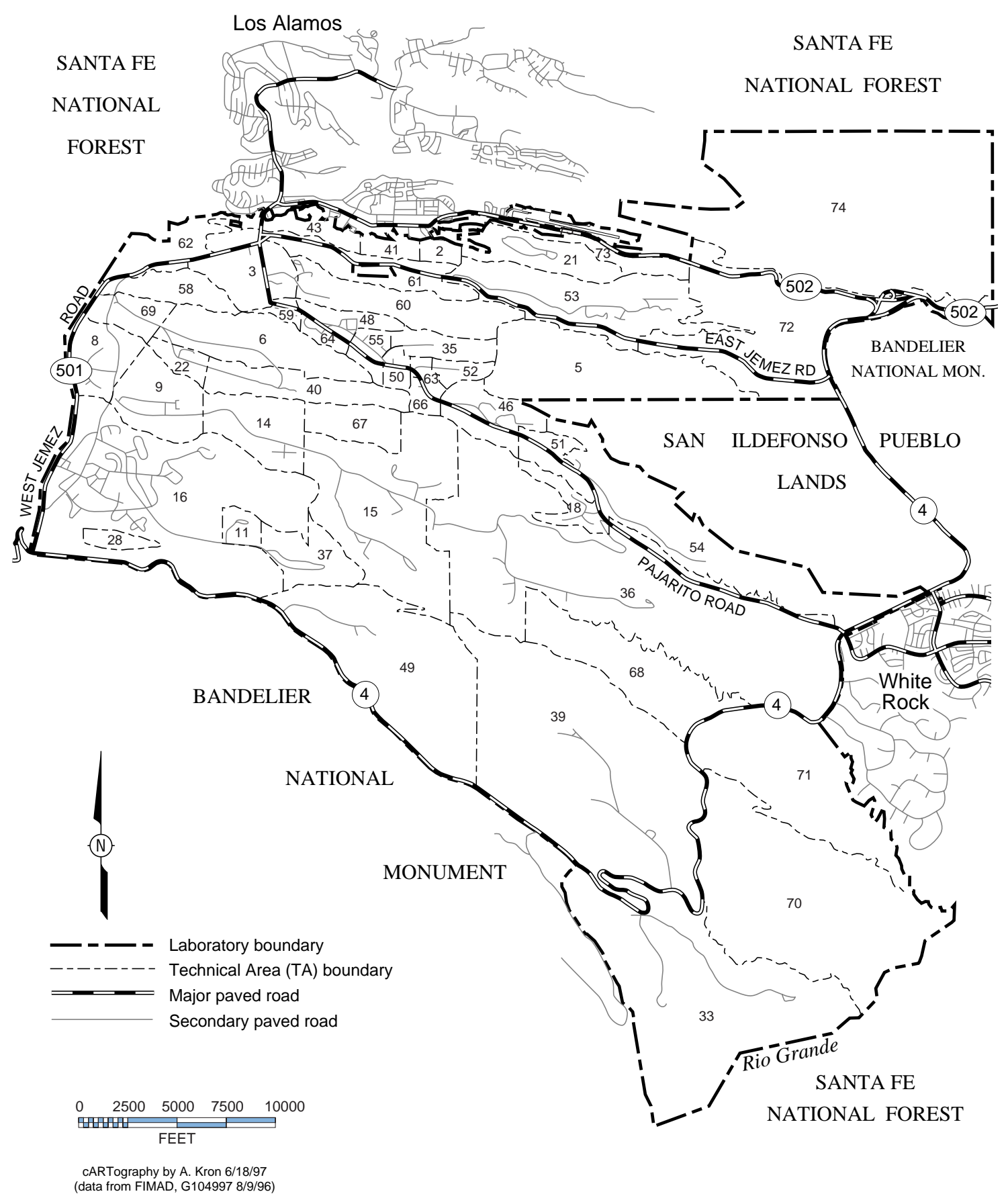

Figure 2. Los Alamos National Laboratory technical areas by number. 
1999 LANL Radionuclide Air Emissions Report

TA-3-35: The facility houses a 5,000-ton capacity press that has been used in the metalworking of radioactive materials.

TA-3-102: This machine shop is used for the metalworking of radioactive materials, primarily depleted uranium.

TA-15-PHERMEX and TA-36: These facilities conduct open-air explosive tests involving depleted uranium.

TA-16-205, TA-21-155, and TA-21-209: These facilities conduct operations involving tritium. Programs include testing of tritium control systems for the nuclear fusion program (TA-21-155), preparation of targets containing tritium for laser-fusion research, and the handling of tritium for defense programs. Tritium recovery operations from old equipment are being conducted at TA-21-209.

TA-18: This nuclear facility studies the behavior of critical assemblies of nuclear materials. Some of the assemblies are used as a source of fission neutrons for experimental purposes, resulting in a diffuse source of Ar-41 emissions.

TA-21: Many of the facilities at this decommissioned radiochemistry site are undergoing decontamination, demolition, and disposal. Some of these operations may contribute to diffuse releases of uranium and plutonium into the air.

TA-33-86 and TA-41-4: These buildings were formerly used as tritium-handling facilities. All accountable tritium has been removed, and current emissions primarily result from residual tritium contamination and cleanup operations.

TA-48-1: The principal activities carried out in this facility are radiochemical separations in support of the medical radioisotope production program, the Yucca Mountain program, nuclear chemistry experiments, and geochemical and environmental research. These separations involve $\mathrm{nCi}$ to $\mathrm{Ci}$ (hot cell) amounts of radioactive materials and use a wide range of analytical chemical separation techniques, such as ion exchange, solvent extraction, mass spectroscopy, plasma emission spectroscopy, and ion chromatography.

TA-50-1: This waste management site consists of a low-level liquid waste treatment plant. Also, there is a wastewater outfall from TA-50-1 that results in a diffuse source of airborne tritium.

TA-50-37: This controlled air incinerator was decommissioned in 1996 and is no longer active. It has been remodeled to house the Radioactive Materials Research Operations Demonstration (RAMROD) project.

TA-50-69: This waste management site consists of a waste characterization and reduction facility.

TA-53: This technical area houses the Los Alamos Neutron Science Center (LANSCE), a linear particle accelerator complex. The accelerator is used to conduct research in stockpile stewardship, radiobiology, materials science, and isotope production, among other areas. LANSCE consists of the Manuel Lujan Neutron Scattering Center, the Proton Storage Ring, the Weapons Neutron Research facility, the Proton Radiography facility, and the high-intensity beam line (Line A). 
1999 LANL Radionuclide Air Emissions Report

The facility accelerates protons and H-ions to an energy of $800 \mathrm{MeV}$ into target materials such as graphite and tungsten to produce neutrons and other subatomic particles. The design current of the accelerator is approximately 1000 microamperes. The primary high-intensity beam line (Line A) and medical isotope production facility did not operate in 1999. Medium (100 microamp) intensity beam operations to the Proton Storage Ring (PSR) and the Manuel Lujan Neutron Scattering Center were conducted in January of 1999. Low-intensity beam (up to 10 microamps) operations to the PSR, the Weapons Neutron Research facility, and the Proton Radiography facility were conducted in January 1999 and May to December of 1999.

Airborne radioactive emissions result from the proton beams and secondary particles passing through and activating air in the target cells, beam stop, and surrounding areas. The majority of the emissions are short-lived activation products such as $\mathrm{C}-11, \mathrm{~N}-13$, and $\mathrm{O}-15$. Most of the activated air is vented through the main stacks; however, a fraction of the activated air becomes a fugitive emission from the target areas. In addition, there are three wastewater lagoons at TA-53 that have received radioactive liquid effluents from the accelerator; however, none of these lagoons received wastewater in 1999, and the old lagoon facility is being remedied. Two new solar evaporative basins were constructed and began operation in 1999 to evaporate wastewater from the accelerator. Evaporation of water from these facilities can result in a diffuse source of airborne tritium.

TA-54: This waste management site consists of active and inactive shallow land burial sites for solid waste and is the primary storage area for mixed and transuranic radioactive waste. Area G at TA-54 is a known source of diffuse emissions of tritium vapor. Resuspension of soil contaminated with low levels of plutonium/americium has also created a diffuse source.

TA-55-4: As discussed in the January 1999 Site-Wide Environmental Impact Statement for Continued Operation of the Los Alamos National Laboratory, this plutonium facility is slated for a plutonium pit production mission as well as for continuing in its traditional role of housing research and development applications in chemical and metallurgical processes for recovering, purifying, and converting plutonium and other actinides. ${ }^{1}$ A wide range of activities that include the heating, dissolution, forming, welding, etc., of special nuclear materials are conducted. Additional activities include the means to safely ship, receive, handle, and store nuclear materials, as well as manage the wastes and residues produced by TA-55 operations. 


\section{Section II. Air Emissions Data}

\subsection{4(b)(4) Point Sources}

Sampled and unsampled point sources at LANL are listed in Table 1. Each entry is identified by technical area and building. Also listed in Table 1 are type, number, and efficiency of the effluent controls used on the release points. Each stage of the high-efficiency particulate air (HEPA) exhaust filters is tested at least once every 12 months. The performance criteria for HEPA filter systems are a maximum penetration of $5 \times 10^{-4}$ for one stage and $2.5 \times 10^{-7}$ for two stages in series, in which penetration equals concentration of aerosol downstream of the air cleaner divided by concentration upstream.

The distance between the point source and the nearest receptor is provided in Table 2. The nearest receptor can be a residence, school, business, or office. In this report, the nearest receptor is defined as the public receptor most impacted by a given release point; that is, the air dispersion pattern is taken into account to determine the nearest or critical receptor location. The distance to the nearest farm producing milk is $20 \mathrm{~km}$ east of the Laboratory's eastern boundary; the nearest farms producing meat and vegetables adjoin the Laboratory's eastern boundary, about $4 \mathrm{~km}$ from the main exhaust stack at LANSCE. More detailed agricultural information can be found in a supplemental LANL report. $^{2}$ At this time, LANL is not using this site-specific agricultural data in the CAP88 model; preprogrammed or default values for New Mexico are utilized for the number of beef and milk cattle and for agricultural productivity.

In addition to 31 monitored release points, approximately 40 unmonitored release points in more than 30 LANL buildings are included in Table 1. Under 40 CFR 61.93(b)(4)(i), sampling of these release points is not required because each release point has a potential effective dose equivalent of less than $0.1 \mathrm{mrem} / \mathrm{yr}$ at the critical receptor. However, in order to verify that emissions from unmonitored point sources remain low, LANL conducts periodic confirmatory measurements in the form of the Radioactive Materials Usage Survey. The purpose of the Usage Survey is to collect and analyze radioactive materials usage and process information for the monitored and unmonitored point sources at LANL.

Guidance in Appendix D to 40 CFR 61, engineering calculations, and other methods are used to develop conservative emissions estimates from unmonitored point sources using the data collected from the facilities. Estimated potential effective dose equivalents (PEDEs) are calculated by modeling these emissions estimates using the EPA-approved CAP88 dose modeling software. A comprehensive survey of all of LANL's monitored and unmonitored point sources is conducted annually or biannually. Results of the 1999 Usage Survey can be found in the report 1999 Radioactive Materials Usage Survey for Point Sources. ${ }^{3}$ The Laboratory has established administrative requirements to evaluate all potential new sources. These requirements are established for the review of all new Laboratory activities and projects to ensure that air quality regulatory requirements will be met before the activity or project begins. ${ }^{4}$ 
1999 LANL Radionuclide Air Emissions Report

\section{Non-Point Sources}

There are a variety of non-point sources within the 111 square kilometers of land occupied by LANL. Nonpoint sources can occur as diffuse or large area sources or as leaks or fugitive emissions from facilities. Examples of non-point sources of airborne radionuclides include surface impoundments, shallow land burial sites, open burn sites, firing sites, outfalls, container storage areas, unvented buildings, waste treatment areas, solid waste management units, and tanks. The Laboratory measures annual average ambient concentrations of important airborne radionuclides (other than activated gases) at a number of potential receptor locations as described below.

Beginning in 1995, LANL began summarizing the potential impacts of nonpoint sources by analyzing and reporting air concentration measurements collected at 17 ambient air-sampling sites around the Laboratory. Previously, LANL had estimated emissions from the most significant nonpoint sources and determined the impacts using EPA's dose assessment computer program. The Laboratory and EPA negotiated this new method of assessing non-point sources as part of a Federal Facility Compliance Agreement (FFCA). ${ }^{5}$ Results of the air sampling analysis are provided in Section III of this report. There were no unexplained readings measured at the air sampling stations in 1999.

\section{Radionuclide Emissions}

Radionuclides released from sampled point sources, along with the annual release rate for each radionuclide, are documented in Table 9. The point sources are identified using an eight-digit identification number for each exhaust stack (ESIDNUM): the first two digits represent the LANL technical area, the next four digits the building area, and the last two digits the stack number. No detectable emissions are denoted as ND.

\section{Pollution Controls}

At Los Alamos National Laboratory the most common type of filtration, for emission control purposes, is the high efficiency particulate air (HEPA) filter. HEPA filters are constructed of sub-micrometer glass fibers that are pressed and glued into a compact, paper-like, pleated media. The paper media is folded alternately over corrugated separators and mounted into a metal or wood frame in eight standard sizes and airflow capacities. A Type I nuclear grade HEPA filter is capable of removing $99.97 \%$ of $0.3 \mu \mathrm{m}$ particles at rated airflow. Other types of filters used in ventilation systems are Aerosol 95, RIGA-FLOW 220, and FARR 30/30. These units are typically used as prefilters in HEPA filtration systems. These filters are significantly less efficient than HEPA filters and are typically used for collecting particulate matter larger than $5 \mu \mathrm{m}$. The above mentioned filters are only effective for particles. When the contaminant of concern is in the form of a gas, activated charcoal beds are used. Charcoal beds collect the gas contaminant through an adsorption process in which the gas comes in contact with the charcoal and adheres to the surface of the charcoal. The charcoal can be coated with different types of materials to make the adsorption process more efficient for different types of contaminants. Typically charcoal beds can achieve an efficiency of $98 \%$ capture with a resident time of 0.25 seconds. 
Tritium effluent controls are generally composed of a catalytic reactor and a molecular sieve bed (CR/MS). Tritium-contaminated effluent is passed through a catalyst that converts elemental tritium (HT) into tritium oxide (HTO). This HTO is then collected as water on a molecular sieve bed. This process can be repeated until the tritium level is at, or below, the desired level. The effluent is then vented through the stack. 


\section{Section III. Dose Assessment}

\subsection{4(b)(7) Description of Dose Calculations}

Effective dose equivalent (or dose) calculations for point sources, unsampled point sources, and non-point gaseous activation products from LANSCE and TA-18 were performed with the mainframe CAP88 version of AIRDOS. This procedure included using PREPAR to prepare the input file to AIRDOS and using the DARTAB preprocessor to prepare the dose conversion factor input file for DARTAB. The calculations used dose conversion factors taken from the RADRISK database that was distributed along with the CAP88 programs. ${ }^{6}$ Verification of the CAP88 code is performed regularly by running the EPA test cases originally distributed with the mainframe version. $^{7}$

\section{Development of Source Term}

\section{Tritium emissions}

Tritium emissions from the Laboratory's tritium facilities are measured using a collection device known as a bubbler. This device enables the Laboratory to determine not only the total amount of tritium released but also whether it is in the elemental (HT) or oxide (HTO) form. The bubbler operates by pulling a continuous sample of air from the stack, which is then "bubbled" through three sequential vials containing ethylene glycol. The ethylene glycol collects the water vapor from the sample of air, including any tritium that is part of a water molecule (tritium oxide or HTO). After the air sample is "bubbled" through these three vials, essentially all HTO is removed from the air, leaving elemental tritium or HT. The sample, containing the elemental tritium, is then passed through a palladium catalyst that converts the elemental tritium to HTO. The sample is pulled through three additional vials containing ethylene glycol, which collects the newly formed HTO. The amount of HTO and HT is determined by analyzing the ethylene glycol for the presence of tritium using liquid scintillation counting (LSC). Although LANL's measurement device can distinguish the presence of HTO from HT, all emissions of tritium are assumed to be HTO for modeling the off-site dose. Because HTO contributes approximately 20,000 times more dose than an equivalent amount of HT, this is a conservative measure that further ensures that the dose to an off-site receptor is not underestimated.

Tritium emissions from LANSCE (which do not require monitoring under 40 CFR 61.93(b)(4)(i)) are determined using a silica gel sampler. A sample of stack air is pulled through a cartridge containing silica gel. The silica gel collects the water vapor from the air, including any HTO. The water is distilled from the sample, and the amount of HTO is determined by analyzing the water using LSC. Because the primary source for tritium at LANSCE is activated water, sampling for only HTO is appropriate. These results are also corrected using the absolute humidity measured in the stack.

\section{Radioactive particle emissions}

Emissions of radioactive particulate matter, generated by operations at facilities such as the Chemistry and Metallurgy Research (CMR) Building and TA-55, are sampled using a glass-fiber filter. A continuous sample of 
1999 LANL Radionuclide Air Emissions Report

stack air is pulled through the filter, where small particles of radioactive material are captured. These samples are analyzed weekly using gross alpha/beta counting and gamma spectroscopy to identify any increase in emissions and to identify short-lived radioactive materials. Every six months, LANL composites these samples for subsequent analysis at an off-site Laboratory. These composite samples are analyzed to determine the total activity of materials such as uranium-234/235/238, plutonium-238/239/240, and americium-241. These data are then combined with estimates of sampling losses and stack and sample flows to calculate emissions. For the case of radionuclides that have short-lived daughters, LANL includes these progeny in the source term. For example, the analytical laboratory measures the parent radionuclide $\mathrm{U}-238$, and its short-lived progeny (Th-234 and $\mathrm{Pa}-234 \mathrm{~m}$ ) are assumed to be in equilibrium with U-238.

\section{Vapor form emissions}

Vapor emissions, generated by LANSCE operations and by hot cell activities at CMR and TA-48, are sampled using a charcoal filter or canister. A continuous sample of stack air is pulled through a charcoal filter where vaporous emissions of radionuclides are adsorbed. The amount and identity of the radionuclide(s) present on the filter are determined through the use of gamma spectroscopy. This information is then used to calculate emissions. Radionuclides of this type include Ga-68, Ge-68, Br-82, and Hg-197.

\section{Gaseous mixed activation products (GMAP)}

GMAP emissions, resulting from activities at LANSCE, are measured using near real-time monitoring data. A sample of stack air is pulled through an ionization chamber that measures the total amount of radioactivity in the sample. Specific radioisotopes are identified through the use of gamma spectroscopy and decay curves. This information is then used to calculate emissions. Radionuclides of this type include C-11, N-13, and O-15.

\section{Summary of input parameters}

Effective dose equivalents to potential receptors were calculated for all radioactive air emissions from sampled LANL point sources. Input parameters for these point sources are provided in Table 3. The geographic locations of the release points, given in NM State Plane coordinates, are provided in Table 4. The relationships of receptor locations to the individual release points are provided in Table 5. The nearest receptor location is different for each point source. However, because the majority of the yearly dose has historically been caused by LANSCE emissions, the LANSCE critical receptor location has historically been the maximum dose location for all Laboratory emissions. This location is a business office approximately 800 meters north-northeast of the LANSCE stack. Emissions and doses from LANSCE are calculated on a monthly basis during beam operations to ensure continued compliance with the $10 \mathrm{mrem} / \mathrm{yr}$ standard.

Other site-specific parameters and the source of these data are provided in Table 6. The LANL Air Quality Group operates an on-site network of meteorological monitoring towers. Data gathered by the towers are summarized and formatted for input to the CAP88 program. For 1999, data from four different towers were used for the air dispersion modeling; the tower data most representative of the release point is applied. Copies of the meteorological data files used for the 1999 dose assessment are provided in Table 7. 
1999 LANL Radionuclide Air Emissions Report

The Air Quality Group also inputs population array data to the CAP88 program. The data file represents a 16sector polar-type array, with 20 radial distances for each sector. Population arrays are developed for each release point using US Census data, updated with annual projections. An example of the population array used for the LANSCE facility is provided in Table 8. For agricultural array input, LANL is currently using the default values in CAP88. Finally, the radionuclide inputs for the point sources monitored in 1999 are provided in Table 9.

\section{Public receptors}

Compliance with the annual dose standard is determined by calculating the highest effective dose equivalent to any member of the public at any off-site point where there is a residence, school, business, or office. Late in the calendar year, a visual tour of the Laboratory vicinity was completed to identify new locations inhabited by the public; that is, new off-site public receptors that had not existed in the year previous to this assessment were identified. Many new businesses and residences were noted in the 1999 tour. For example, there are several new residences at the Royal Crest Trailer Park. One of these new residences became the nearest new off-site point for the TA-48 facility (in this report, the nearest off-site point is defined as the area of public habitation where the highest off-site dose occurs for a given emissions source). For the 1999 compliance assessment, LANL-wide doses were evaluated at the nearest off-site point for each monitored emissions stack, as well as at a number of additional key locations.

\section{Point Source Emissions Modeling}

The CAP88 program was used to calculate doses from both the monitored and unmonitored point sources at LANL. The CAP88 program uses on-site meteorological data to calculate atmospheric dispersion and transport of the radioactive effluents. There are a number of radionuclides monitored in LANL effluents that are not included in the dose factor database used by CAP88. ${ }^{7}$ For the substantial GMAP effluents such as C-10, N-16, and O-14, LANL uses a revised set of CAP88 database files to which the required dose factors have been added. For other effluents such as Ga-68, Ge-68, Br-82, Hg-197, etc., LANL uses the CAP88 code to calculate environmental concentrations of these radionuclides at the receptor locations and then applies an appropriate dose factor to estimate dose.

\section{LANSCE Fugitive Emission Modeling}

Some of the gaseous mixed activation products (GMAP) created at the accelerator target cells migrate into room air and into the environment. These fugitive sources are continuously monitored throughout the beam-operating period. In 1999, approximately $17.1 \mathrm{Ci}$ of C-11 and $0.7 \mathrm{Ci}$ of Ar-41 were released from LANSCE as fugitive emissions. This source was modeled as an area source, using CAP88 and meteorological data coinciding with the LANSCE run cycle. Fugitive effluents were modeled from one area at LANSCE; additional source information is provided in Table 10. 


\section{TA-18 Non-Point Emission Modeling}

This site consists of a variety of nuclear assemblies that are operated at near-critical conditions. During the near-critical operations, neutrons are generated that, in turn, activate argon atoms in the air surrounding the assembly. Operations conducted in 1999 were evaluated for their potential to create Ar-41 gas. In 1999, approximately $0.49 \mathrm{Ci}$ of Ar-41 was generated and the dose evaluated with CAP88. Additional source information is provided in Table 10 .

\section{Radionuclides Not Included in CAP88}

Some of the radionuclides detected in LANL air effluents are not included in the CAP88 library of exposure-todose conversion factors. As previously mentioned, LANL added dose coefficients to the CAP88 data files for three routinely emitted radionuclides: C-10, N-16, and O-14. Because of the unique emissions from LANSCE and other facilities, other radionuclides not included in CAP88 are emitted on an infrequent basis. Examples of such radionuclides detected in LANL air effluents during 1999 are included in Table 9 and are listed separately in Table 11.

To calculate the dose from these particular radionuclides, LANL uses several methods. LANL uses the mainframe version of CAP88 to calculate the air concentration at the receptor location of interest. In most cases the air concentration can be then converted into a dose by applying the conversions given in Table 2 of Appendix E of 40 CFR 61, which has a more extensive list of radionuclides than CAP88. ${ }^{8}$ In some cases, LANL obtains exposureto-dose conversion factors from other sources, such as EPA's Federal Guidance Reports.9,10 Dose conversion factors used for radionuclides not included in CAP88 but found in LANL air effluents during 1999 are provided in Table 12.

At the LANL-wide maximum dose location for 1999, the total estimated dose arising from emissions of radionuclides not included in the CAP88 library was about $0.001 \mathrm{mrem}$. This number is included in the total annual dose. The LANL Air Quality Group has informed the Regional Office of the U.S. EPA of the various steps and methods used to calculate the doses from such radionuclides. ${ }^{11}$

\section{Environmental Data}

The net annual average ambient concentration of airborne radionuclides measured at 17 air sampling stations (Fig. 3) is calculated by subtracting an appropriate background concentration value. The net concentration is converted to an annual effective dose equivalent (EDE) using Table 2 of Appendix E of 40 CFR 61 and applying the valid assumption that each table value is equivalent to $10 \mathrm{mrem} / \mathrm{yr}$ from all appropriate exposure pathways (100\% occupancy assumed at the respective location). ${ }^{8}$ Results from each air sampler are given in Table 13. The operational performance of each air sampler is provided in Table 14. 


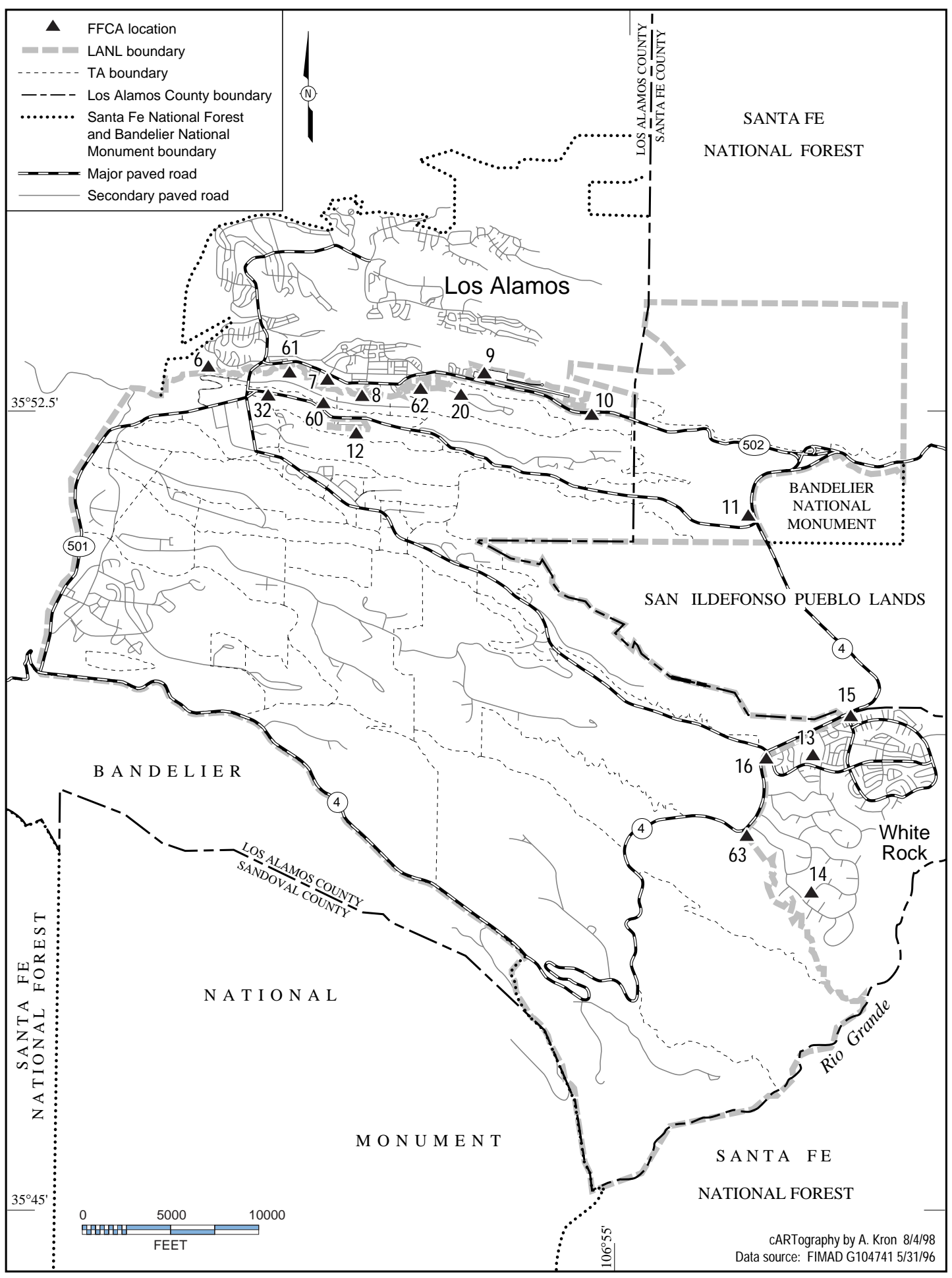

Figure 3. Locations of air sampling stations used for non-point source compliance. 
1999 LANL Radionuclide Air Emissions Report

\section{LANSCE Monthly Assessments}

The Air Quality Group evaluates the dose from short-lived radioactive gases released from LANSCE on a monthly basis. The monthly dose values are evaluated with the actual meteorology for the month and these doses are given in Table 15. The Air Quality Group also evaluates the annual LANSCE emissions with annual average meteorology and compares the results to the monthly values summed for the calendar year; the values for these two assessments were $1.16 \mathrm{e}-02$ and $1.11 \mathrm{e}-02$, respectively.

\section{Highest EDE Determination}

A major change to the procedure for determining the highest EDE was necessary for 1999 because of significantly reduced emissions from the LANSCE facility. Over the past nine years, the off-site EDE due to LANSCE operations has averaged about 5 mrem. For 1999, the highest off-site EDE from the LANSCE facility was 1.16e-02 mrem. The highest off-site EDE location for LANSCE effluents is a business office in the East Gate area (2470 East Gate Drive). Since the contribution from LANSCE for 1999 is greatly reduced, the location of the highest off-site dose is not as readily established as had been in the past.

In late 1999, LANL began working on a plan to ensure that the location of the highest public dose could be determined. This plan uses a multi-step approach, and the steps used were presented to the local Citizen's Advisory Board $(\mathrm{CAB})$ for LANL for their review and comment. In addition, the Air Quality Group requested the CAB to identify additional locations of potential public interest that should be evaluated for off-site dose. Table 16 shows the locations identified by both LANL and the CAB for the purposes of finding the location of the highest off-site dose. Also shown in the table is the AIRNET sampling station that the Air Quality Group associated with the selected public receptor location. Some of the locations evaluated for the Los Alamos area are shown in Fig. 4. The 1999 LANL-wide doses at these various off-site locations are also provided in Table 16.

\subsection{Compliance Assessment}

The highest effective dose equivalent to any member of the public at any off-site point where there is a residence, school, or business office was 0.32 mrem for radioactive effluents released by LANL in 1999. This dose was calculated by adding up the doses for each of the point sources at LANL, the diffuse and fugitive gaseous activation products from LANSCE and TA-18, and the dose measured by the ambient air sampler in the vicinity of the public receptor location. The compliance assessment also includes a potential dose contribution of $0.11 \mathrm{mrem}$ from unmonitored stacks. Because the emissions estimates do not account for pollution control systems, the actual dose will be significantly less for the unmonitored point sources. Also, this dose includes an approximate 0.001 mrem contribution from radionuclides not included in CAP88. Table 17 provides the compliance assessment summary. The location of the off-site point of highest EDE for 1999 was the County Landfill business office; this location is different from the location of previous years' assessments. Historically, the highest off-site EDE location was a business office in the East Gate area. Table 17 also lists the LANL-wide doses at this location. 


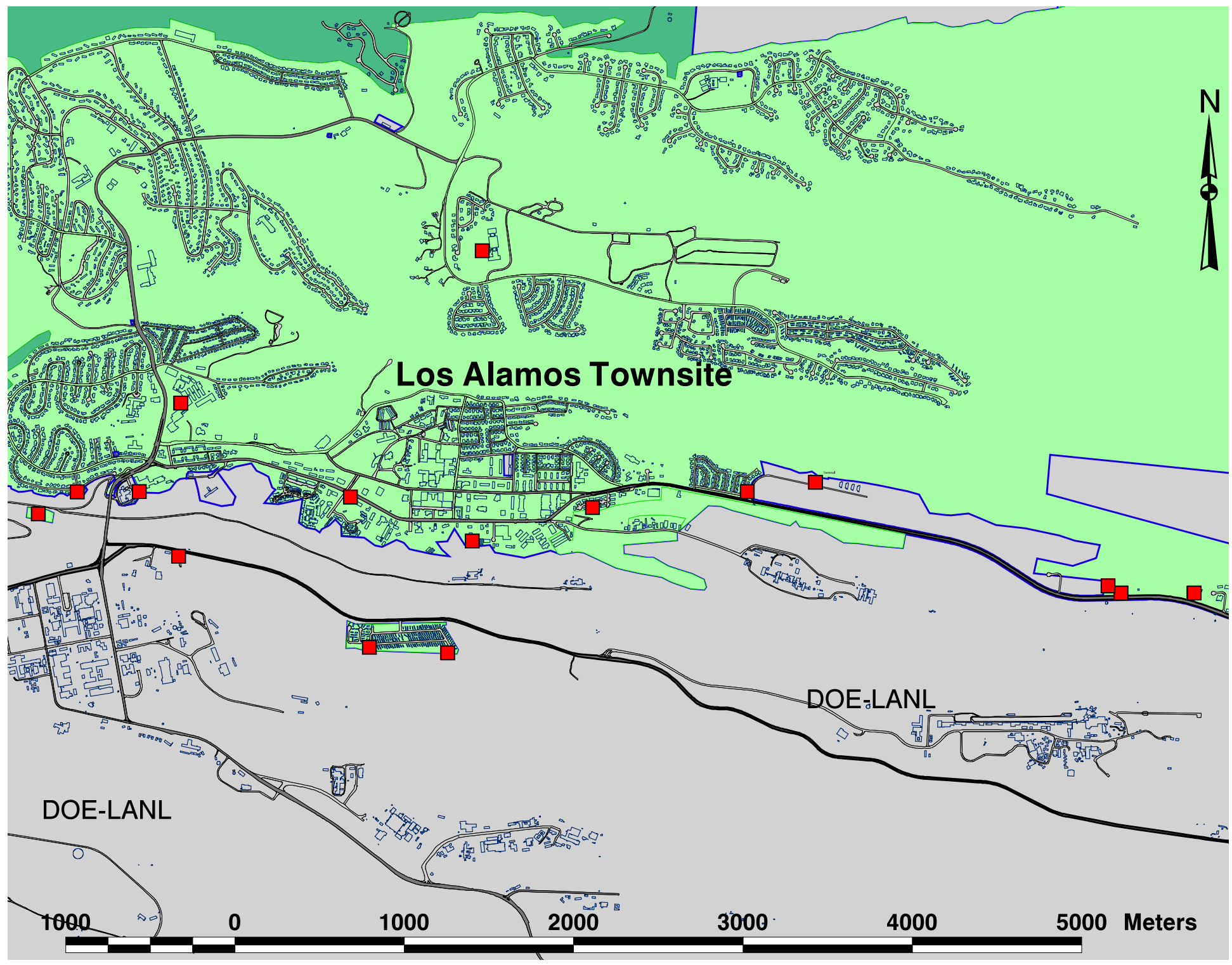

Figure 4. Locations in the Los Alamos townsite area evaluated for off-site dose. 


\section{Section IV. Constructions and Modifications}

\subsection{4(b)(8) Constructions and Modifications}

A brief description of constructions and modifications that were completed and/or reviewed in 1999, but for which the requirement to apply for approval to construct or modify was waived under 61.96, is provided here. The Air Quality Group for LANL/DOE maintains the documentation developed to support the waiver.

\section{Project \#97-0104 Contaminated Records Storage Area}

This project was previously reviewed in the 1997 LANL Radionuclide Air Emissions Report. It is being included again because the Central Weapons Information Center began working with these potentially contaminated records in early 1999. Contaminated records will be stored in the Central Weapons Information Center. Potential contaminants include tritium, alpha contamination, gamma contamination, beryllium, lead, and high explosives residue. Potential contamination from the files is estimated based on typical levels of contamination in trash receptacles and bench tops at TA-21. The maximum level of contamination is estimated to be $0.04 \mathrm{Ci}$ for 1000 boxes. In order to determine the applicability of NESHAP requirements, a dose assessment was calculated using CAP88-PC. Based on the modeling results, the potential effective dose equivalent at the nearest receptor is 0.02 $\mathrm{mrem} / \mathrm{yr}$ and is well below the stack monitoring and construction approval threshold of $0.1 \mathrm{mrem} / \mathrm{yr}$.

\section{Project \#99-0050 Volume Reduction Evaporator}

The Volume Reduction Evaporator project involves the installation of evaporation equipment at TA-50-248. The equipment will consist of a 10 million Btu natural gas-fired boiler, a cooling tower, and an evaporation unit. Steam from the boiler will be used to heat the evaporation unit, and the cooling tower will be used to facilitate condensation functions of the evaporation unit.

The waste stream is not new and is not increasing in quantity or in radionuclide concentration. Therefore, the potential emissions from the waste treatment operations are not increasing. Changes to the waste treatment are being made to reduce the contaminants that are in the final liquid discharge.

The process involves the volume reduction of radionuclide-contaminated liquid effluent from reverse osmosis and electrodialysis reversal units at TA-50-1 by evaporation within a sealed evaporator/condenser unit. The radionuclide-contaminated evaporator bottoms from the evaporator/condenser unit will be pumped into a holding tank. Although the evaporator/condenser unit is a sealed source, the evaporator bottoms holding tank has an opening in the top of it to allow air to diffuse while the evaporator bottoms are pumped in.

Dose assessments were calculated using CAP88. Maximum operation of this unit will be no more than 150 days per year. In order to conduct a conservative emissions estimate, it is assumed that the unit operates 365 days per year. The average alpha radioactivity level in the concentrate for the calendar year 1999 was $0.017 \mathrm{Ci} / \mathrm{yr}$. Using this information and Appendix D emission factors, ${ }^{8}$ modeling indicates the maximum potential effective dose equivalent from the source at the nearest receptor is $0.003 \mathrm{mrem} / \mathrm{yr}$. This is well below the monitoring and permitting threshold of $0.1 \mathrm{mrem} / \mathrm{yr}$ specified in the NESHAP. The start-up date for this operation was January 31 , 2000 . 


\section{Section V. Additional Information}

This following section is provided pursuant to DOE guidance and is not required by Subpart $\mathrm{H}$ reporting requirements.

\section{Unplanned Releases}

During 1999, the Laboratory had no instances of increased airborne emissions of radioactive materials that required reporting to the Environmental Protection Agency.

There were two instances of unplanned releases due to process problems. First, during the week of June 4, 1999, a small release of a radioactive form of silicon, Si-32, occurred at the Radiochemistry facility, TA-48. This release comprised $5 \mu \mathrm{Ci}$ and had a dose impact less than $0.001 \mathrm{mrem}$. The second unplanned release was noted during the week of June 25, 1999. An operation at the Chemistry and Metallurgy Research (CMR) facility resulted in a small release of a radioactive form of technetium, Tc-99. During an operation involving the heating of enriched uranium, any Tc-99 present in the sample is volatilized. Because of an equipment malfunction, this Tc-99 was released to the room and subsequently vented through the stack. This release comprised $50 \mu \mathrm{Ci}$ and had a dose impact less than $0.001 \mathrm{mrem}$.

\section{Environmental Monitoring}

The LANL Air Quality Group operates an extensive environmental monitoring network that includes several environmental monitoring stations located near the LANSCE boundary inhabited by the public. Measurement systems at these stations include LiF thermoluminescent dosimeters, continuously operated air samplers, and in situ high-pressure ion chambers. The combination of these measurement systems allows for monitoring of radionuclide air concentrations and the radiation exposure rate. Results for air sampling are published here and results for all monitoring data are published in the Annual Site Environmental Surveillance Report for DOE Order compliance.

\section{Other Supplemental Information}

- Collective effective dose equivalent for 1999 airborne releases: 0.32 person-rem.

- $\quad$ Compliance with Subparts Q and T of 40 CFR 61 - Radon-222 Emissions.

These regulations apply to Rn-222 emissions from DOE storage/disposal facilities that contain byproduct material. "Byproduct material" is the tailings or wastes produced by the extraction or concentration of uranium from ore. Although this regulation targets uranium mills, LANL has likely stored small amounts of byproduct material used in experiments in the TA-54 low-level waste facility, Area G, and this practice makes the Laboratory subject to this regulation. Subject facilities cannot exceed an emissions rate of $20 \mathrm{pCi} / \mathrm{m}^{2} \mathrm{~s}$ of Rn222. In 1993 and 1994, LANL conducted a study to characterize emissions from the Area G disposal site. ${ }^{12}$ This study showed an average emission rate of $0.14 \mathrm{pCi} / \mathrm{m}^{2} \mathrm{~s}$ for Area G. The performance assessment for Area $\mathrm{G}$ has determined that there will not be a significant increase in Rn-222 emissions in the future. ${ }^{13}$ 
- $\quad$ Potential to exceed 0.1 mrem from LANL sources of Rn-222 or Rn-220 emissions: not applicable at LANL.

- Status of compliance with EPA effluent monitoring requirements: As of June 3, 1996, LANL came into compliance with EPA effluent monitoring requirements. 
Table 1. 40-61.94(b)(4-5) Release Point Data

\begin{tabular}{|c|c|c|c|c|c|}
\hline ESIDNUM & Location & $\begin{array}{c}\text { Control } \\
\text { Description }\end{array}$ & $\begin{array}{c}\text { Number of } \\
\text { Effluent Controls }\end{array}$ & $\begin{array}{c}\text { Control } \\
\text { Efficiency }\end{array}$ & Monitored \\
\hline 03001608 & TA-03-16 & none & 0 & $0 \%$ & $\square$ \\
\hline 03001609 & TA-03-16 & none & 0 & $0 \%$ & $\square$ \\
\hline 03001614 & TA-03-16 & none & 0 & $0 \%$ & $\square$ \\
\hline 03001616 & TA-03-16 & none & 0 & $0 \%$ & $\square$ \\
\hline 03001621 & TA-03-16 & none & 0 & $0 \%$ & $\square$ \\
\hline 03001641 & TA-03-16 & none & 0 & $0 \%$ & $\square$ \\
\hline 03002913 & TA-03-29-1 & unkown & 0 & $0 \%$ & $\square$ \\
\hline 03002914 & TA-03-29-2 & HEPA & 2 & $99.95 \%$ each & $\nabla$ \\
\hline 03002915 & TA-03-29-2 & HEPA & 2 & $99.95 \%$ each & $\square$ \\
\hline 03002919 & TA-03-29-3 & Aerosol 95 & 1 & $80 \%$ & $\nabla$ \\
\hline 03002920 & TA-03-29-3 & Aerosol 95 & 1 & $80 \%$ & $\nabla$ \\
\hline 03002921 & TA-03-29-3 & none & 0 & $0 \%$ & $\square$ \\
\hline 03002923 & TA-03-29-4 & FARR 30/30 & 1 & $\sim 20 \%$ & $\nabla$ \\
\hline 03002924 & TA-03-29-4 & FARR 30/30 & 1 & $\sim 20 \%$ & $\nabla$ \\
\hline 03002928 & TA-03-29-5 & HEPA & 2 & $99.95 \%$ each & $\nabla$ \\
\hline 03002929 & TA-03-29-5 & HEPA & 2 & $99.95 \%$ each & $\nabla$ \\
\hline 03002932 & TA-03-29-7 & HEPA & 2 & $99.95 \%$ each & $\nabla$ \\
\hline 03002933 & TA-03-29-7 & HEPA & 2 & $99.95 \%$ each & $\nabla$ \\
\hline 03002937 & TA-03-29-V & HEPA & 2 & $99.95 \%$ each & $\nabla$ \\
\hline 03002944 & TA-03-29-9 & RIGA-Flow 220 & 1 & $80 \%$ & $\nabla$ \\
\hline 03002945 & TA-03-29-9 & RIGA-Flow 220 & 1 & $80 \%$ & $\nabla$ \\
\hline 03002946 & TA-03-29-9 & RIGA-Flow 220 & 1 & $80 \%$ & $\square$ \\
\hline 03003401 & TA-03-34 & none & 0 & $0 \%$ & $\square$ \\
\hline 03003435 & TA-03-34 & none & 0 & $0 \%$ & $\square$ \\
\hline 03003501 & TA-03-35 & HEPA & 1 & $99.95 \%$ & $\nabla$ \\
\hline 03003999 & TA-3-39 & none & 0 & $0 \%$ & $\square$ \\
\hline 03004025 & TA-03-40 & HEPA & 1 & $99.95 \%$ & $\square$ \\
\hline 03006601 & TA-03-66 & none & 0 & $0 \%$ & $\square$ \\
\hline 03006602 & TA-03-66 & none & 0 & $0 \%$ & $\square$ \\
\hline 03006603 & TA-03-66 & none & 0 & $0 \%$ & $\square$ \\
\hline 03006604 & TA-03-66 & none & 0 & $0 \%$ & $\square$ \\
\hline 03006605 & TA-03-66 & none & 0 & $0 \%$ & $\square$ \\
\hline
\end{tabular}


Table 1. 40-61.94(b)(4-5) Release Point Data (continued)

\begin{tabular}{|c|c|c|c|c|c|}
\hline ESIDNUM & Location & $\begin{array}{c}\text { Control } \\
\text { Description }\end{array}$ & $\begin{array}{l}\text { Number of } \\
\text { Effluent Controls }\end{array}$ & $\begin{array}{c}\text { Control } \\
\text { Efficiency }\end{array}$ & Monitored \\
\hline 03006626 & TA-03-66 & HEPA & 1 & $99.95 \%$ & $\square$ \\
\hline 03006643 & TA-03-66 & none & 0 & $0 \%$ & $\square$ \\
\hline 03010222 & TA-03-102 & HEPA & 1 & $99.95 \%$ & $\nabla$ \\
\hline 03010225 & TA-03-102 & HEPA & 1 & $99.95 \%$ & $\square$ \\
\hline 03014110 & TA-03-141 & none & 0 & $0 \%$ & $\square$ \\
\hline 03169801 & TA-03-1698 & none & 0 & $0 \%$ & $\square$ \\
\hline 09002103 & TA-09-21 & none & 0 & $0 \%$ & $\square$ \\
\hline 09003201 & TA-09-32 & none & 0 & $0 \%$ & $\square$ \\
\hline 15044699 & TA-15-446 & none & 0 & $0 \%$ & $\square$ \\
\hline 16020504 & TA-16-205 & $\mathrm{CR} / \mathrm{MS}$ & 1 & $>99 \%$ & $\nabla$ \\
\hline 16020599 & TA-16-205 & none & 0 & $0 \%$ & $\square$ \\
\hline 16024801 & TA-16-248 & none & 0 & $0 \%$ & $\square$ \\
\hline 18012701 & TA-18-127 & none & 0 & $0 \%$ & $\square$ \\
\hline 18016801 & TA-18-168 & none & 0 & $0 \%$ & $\square$ \\
\hline 21000507 & TA-21-5 & HEPA & 2 & $99.95 \%$ each & $\square$ \\
\hline $21002 \mathrm{~S} 00$ & TA-21-2S & HEPA & 1 & $99.95 \%$ & $\square$ \\
\hline 21015001 & TA-21-150 & HEPA & 1 & $99.95 \%$ & $\square$ \\
\hline 21015505 & TA-21-155 & $\mathrm{CR} / \mathrm{MS}$ & 1 & $>99 \%$ & $\nabla$ \\
\hline 21020901 & TA-21-209 & CR/MS & 1 & $>99 \%$ & $\nabla$ \\
\hline 21021301 & TA-21-213 & none & 0 & $0 \%$ & $\square$ \\
\hline 21025704 & TA-21-257 & none & 0 & $0 \%$ & $\square$ \\
\hline 21041899 & TA-21-418 & none & 0 & $0 \%$ & $\square$ \\
\hline 33008606 & TA-33-86 & none & 0 & $0 \%$ & $\nabla$ \\
\hline 35021305 & TA-35-213 & none & 0 & $0 \%$ & $\square$ \\
\hline 35021308 & TA-35-213 & none & 0 & $0 \%$ & $\square$ \\
\hline 41000104 & TA-41-1 & HEPA & 2 & $99.95 \%$ each & $\square$ \\
\hline 41000417 & TA-41-4 & none & 0 & $0 \%$ & $\nabla$ \\
\hline 43000102 & TA-43-1 & none & 0 & $0 \%$ & $\square$ \\
\hline 43000109 & TA-43-1 & none & 0 & $0 \%$ & $\square$ \\
\hline 43000110 & TA-43-1 & none & 0 & $0 \%$ & $\square$ \\
\hline 43000112 & TA-43-1 & none & 0 & $0 \%$ & $\square$ \\
\hline 43000113 & TA-43-1 & none & 0 & $0 \%$ & $\square$ \\
\hline
\end{tabular}


Table 1. 40-61.94(b)(4-5) Release Point Data (continued)

\begin{tabular}{|c|c|c|c|c|c|}
\hline ESIDNUM & Location & $\begin{array}{c}\text { Control } \\
\text { Description }\end{array}$ & $\begin{array}{c}\text { Number of } \\
\text { Effluent Controls }\end{array}$ & $\begin{array}{c}\text { Control } \\
\text { Efficiency }\end{array}$ & Monitored \\
\hline 43000134 & TA-43-1 & none & 0 & $0 \%$ & $\square$ \\
\hline 46002401 & TA-46-24 & none & 0 & $0 \%$ & $\square$ \\
\hline 46003101 & TA-46-31 & none & 0 & $0 \%$ & $\square$ \\
\hline 46003125 & TA-46-31 & none & 0 & $0 \%$ & $\square$ \\
\hline 46003141 & TA-46-31 & none & 0 & $0 \%$ & $\square$ \\
\hline 46004106 & TA-46-41 & none & 0 & $0 \%$ & $\square$ \\
\hline 46015405 & TA-46-154 & none & 0 & $0 \%$ & $\square$ \\
\hline 46015810 & TA-46-158 & none & 0 & $0 \%$ & $\square$ \\
\hline 48000107 & TA-48-1 & $\begin{array}{c}\text { HEPA/Charcoal } \\
\text { Bed }\end{array}$ & 2 & $99.95 \%$ each & $\nabla$ \\
\hline 48000111 & TA-48-1 & none & 0 & $0 \%$ & $\square$ \\
\hline 48000115 & TA-48-1 & none & 0 & $0 \%$ & $\square$ \\
\hline 48000135 & TA-48-1 & none & 0 & $0 \%$ & $\square$ \\
\hline 48000145 & TA-48-1 & none & 0 & $0 \%$ & $\square$ \\
\hline 48000154 & TA-48-1 & HEPA & 2 & $99.95 \%$ each & $\nabla$ \\
\hline 48000160 & TA-48-1 & HEPA & 1 & $99.95 \%$ & $\nabla$ \\
\hline 48000199 & TA-48-1 & HEPA & 1 & $99.95 \%$ & \\
\hline 48004501 & TA-48-45 & none & 0 & $0 \%$ & $\square$ \\
\hline 50000102 & TA-50-1 & HEPA & 1 & $99.95 \%$ each & $\nabla$ \\
\hline 50000201 & TA-50-2 & none & 0 & $0 \%$ & $\square$ \\
\hline 50003701 & TA-50-37 & HEPA & 2 & $99.95 \%$ each & $\nabla$ \\
\hline 50006901 & TA-50-69 & HEPA & 1 & $99.95 \%$ & $\square$ \\
\hline 50006902 & TA-50-69 & HEPA & 1 & $99.95 \%$ & $\square$ \\
\hline 50006903 & TA-50-69 & HEPA & 2 & $99.95 \%$ each & $\nabla$ \\
\hline 50018500 & TA-50-185 & HEPA & 1 & $99.95 \%$ & $\square$ \\
\hline 53000303 & TA-53-3 & HEPA & 1 & $99.95 \%$ & $\nabla$ \\
\hline 53000702 & TA-53-7 & HEPA & 1 & $99.95 \%$ & $\nabla$ \\
\hline 53000799 & TA-53-7 & none & 0 & $0 \%$ & $\square$ \\
\hline 53036599 & TA-53-365 & none & 0 & $0 \%$ & $\square$ \\
\hline 53109010 & TA-53-1090 & none & 0 & $0 \%$ & $\square$ \\
\hline 54003300 & TA-54-33 & HEPA & 1 & $99.95 \%$ & $\square$ \\
\hline 54003601 & TA-54-36 & HEPA & 1 & $99.95 \%$ & $\square$ \\
\hline 54022601 & TA-54-226 & none & 0 & $0 \%$ & $\square$ \\
\hline
\end{tabular}


Table 1. 40-61.94(b)(4-5) Release Point Data (continued)

\begin{tabular}{cccccc}
\hline ESIDNUM & Location & $\begin{array}{c}\text { Control } \\
\text { Description }\end{array}$ & $\begin{array}{c}\text { Number of } \\
\text { Effluent Controls }\end{array}$ & $\begin{array}{c}\text { Control } \\
\text { Efficiency }\end{array}$ & Monitored \\
\hline 54028101 & TA-54-281 & HEPA & 1 & $99.95 \%$ & $\square$ \\
54100110 & TA-54-1001 & none & 0 & $0 \%$ & $\square$ \\
55000415 & TA-55-4 & HEPA & 4 & $99.95 \%$ each & $\square$ \\
55000416 & TA-55-4 & HEPA & 4 & $99.95 \%$ each & $\square$ \\
59000104 & TA-59-1 & none & 0 & $0 \%$ & $\square$ \\
59000114 & TA-59-1 & none & 0 & $0 \%$ & $\square$ \\
59000121 & TA-59-1 & none & 0 & $0 \%$ & $\square$ \\
59000122 & TA-59-1 & none & 0 & $0 \%$ & $\square$ \\
59000123 & TA-59-1 & none & 0 & $0 \%$ & $\square$ \\
59000124 & TA-59-1 & none & 0 & $0 \%$ & $\square$ \\
59000125 & TA-59-1 & none & 0 & $0 \%$ & $\square$ \\
59000126 & TA-59-1 & none & 0 & $0 \%$ & $\square$ \\
59000127 & TA-59-1 & none & 0 & $0 \%$ & $\square$ \\
59000130 & TA-59-1 & none & 0 & $0 \%$ & $\square$ \\
\hline
\end{tabular}


1999 LANL Radionuclide Air Emissions Report

Table 2. 40-61.94(b)(6) Distances from Monitored Release Points to Nearest Receptor

\begin{tabular}{|c|c|c|}
\hline ESIDNUM & Nearest Receptor (m) & Receptor Direction \\
\hline 03002914 & 731 & $\mathrm{NE}$ \\
\hline 03002915 & 732 & $\mathrm{NE}$ \\
\hline 03002919 & 836 & NNE \\
\hline 03002920 & 835 & NNE \\
\hline 03002923 & 845 & $\mathrm{NE}$ \\
\hline 03002924 & 846 & $\mathrm{NE}$ \\
\hline 03002928 & 936 & $\mathrm{NE}$ \\
\hline 03002929 & 937 & $\mathrm{NE}$ \\
\hline 03002932 & 856 & NNE \\
\hline 03002933 & 855 & NNE \\
\hline 03002937 & 870 & $\mathrm{NE}$ \\
\hline 03002944 & 937 & NNE \\
\hline 03002945 & 939 & NNE \\
\hline 03002946 & 938 & NNE \\
\hline 03003501 & 691 & NNE \\
\hline 03010222 & 1060 & $\mathrm{NE}$ \\
\hline 16020504 & 778 & SSW \\
\hline 21015505 & 680 & NNW \\
\hline 21020901 & 712 & NNW \\
\hline 33008606 & 977 & WSW \\
\hline 41000417 & 197 & $\mathrm{~N}$ \\
\hline 48000107 & 750 & NNE \\
\hline 48000154 & 751 & NNE \\
\hline 48000160 & 764 & NNE \\
\hline 50000102 & 1183 & $\mathrm{~N}$ \\
\hline 50003701 & 1171 & $\mathrm{~N}$ \\
\hline 50006903 & 1186 & $\mathrm{~N}$ \\
\hline 53000303 & 800 & NNE \\
\hline 53000702 & 944 & NNE \\
\hline 55000415 & 1016 & NNE \\
\hline 55000416 & 1089 & NNE \\
\hline
\end{tabular}


Table 3. 40-61.94(b)(7) User-Supplied Data-Monitored Stack Parameters

\begin{tabular}{|c|c|c|c|}
\hline ESIDNUM & Height (m) & Diameter (m) & Exit Velocity $(\mathrm{m} / \mathrm{s})$ \\
\hline 03002914 & 15.9 & 1.07 & 7.0 \\
\hline 03002915 & 15.9 & 1.07 & 23.6 \\
\hline 03002919 & 15.9 & 1.07 & 25.9 \\
\hline 03002920 & 15.9 & 1.07 & 15.0 \\
\hline 03002923 & 15.9 & 1.07 & 21.9 \\
\hline 03002924 & 15.9 & 1.07 & 15.8 \\
\hline 03002928 & 15.9 & 1.07 & 22.5 \\
\hline 03002929 & 15.9 & 1.07 & 19.8 \\
\hline 03002932 & 15.9 & 1.07 & 18.3 \\
\hline 03002933 & 15.9 & 1.07 & 20.0 \\
\hline 03002937 & 16.8 & 0.20 & 23.4 \\
\hline 03002944 & 16.5 & 1.40 & 11.4 \\
\hline 03002945 & 16.5 & 1.40 & 11.9 \\
\hline 03002946 & 16.5 & 1.80 & 5.5 \\
\hline 03003501 & 12.0 & 0.86 & 6.3 \\
\hline 03010222 & 13.4 & 0.91 & 1.3 \\
\hline 16020504 & 18.3 & 0.46 & 21.2 \\
\hline 21015505 & 29.9 & 0.81 & 8.2 \\
\hline 21020901 & 22.9 & 1.22 & 11.3 \\
\hline 33008606 & 23.4 & 0.56 & 12.1 \\
\hline 41000417 & 30.8 & 1.50 & 3.0 \\
\hline 48000107 & 13.4 & 0.30 & 20.2 \\
\hline 48000154 & 13.1 & 0.91 & 7.1 \\
\hline 48000160 & 12.4 & 0.38 & 13.0 \\
\hline 50000102 & 15.5 & 1.83 & 12.6 \\
\hline 50003701 & 12.4 & 0.91 & 7.9 \\
\hline 50006903 & 10.5 & 0.34 & 4.0 \\
\hline 53000303 & 33.5 & 0.91 & 12.1 \\
\hline 53000702 & 13.1 & 0.91 & 10.0 \\
\hline 55000415 & 9.5 & 0.93 & 9.3 \\
\hline 55000416 & 9.5 & 0.93 & 16.1 \\
\hline
\end{tabular}


Table 4. 69.94(b)(7) User-Supplied Data-Monitored Stack Parameters $-\mathrm{x}$ and $\mathrm{y}$ coordinates

\begin{tabular}{|c|c|c|}
\hline ESIDNUM & Easting & Northing \\
\hline 03002914 & $1,619,176$ & $1,772,806$ \\
\hline 03002915 & $1,619,171$ & $1,772,805$ \\
\hline 03002919 & $1,619,252$ & $1,772,350$ \\
\hline 03002920 & $1,619,257$ & $1,772,352$ \\
\hline 03002923 & $1,618,691$ & $1,772,719$ \\
\hline 03002924 & $1,618,686$ & $1,772,718$ \\
\hline 03002928 & $1,618,774$ & $1,772,265$ \\
\hline 03002929 & $1,618,767$ & $1,772,265$ \\
\hline 03002932 & $1,619,268$ & $1,772,267$ \\
\hline 03002933 & $1,619,272$ & $1,772,269$ \\
\hline 03002937 & $1,618,966$ & $1,772,397$ \\
\hline 03002944 & $1,618,987$ & $1,772,121$ \\
\hline 03002945 & $1,618,977$ & $1,772,120$ \\
\hline 03002946 & $1,618,982$ & $1,772,121$ \\
\hline 03003501 & $1,619,949$ & $1,772,577$ \\
\hline 03010222 & $1,618,354$ & $1,772,074$ \\
\hline 16020504 & $1,609,447$ & $1,760,866$ \\
\hline 21015505 & $1,633,757$ & $1,774,182$ \\
\hline 21020901 & $1,633,991$ & $1,774,175$ \\
\hline 33008606 & $1,638,721$ & $1,740,076$ \\
\hline 41000417 & $1,626,190$ & $1,774,437$ \\
\hline 48000107 & $1,623,591$ & $1,770,693$ \\
\hline 48000154 & $1,623,744$ & $1,770,650$ \\
\hline 48000160 & $1,623,613$ & $1,770,638$ \\
\hline 50000102 & $1,626,157$ & $1,769,086$ \\
\hline 50003701 & $1,625,757$ & $1,769,109$ \\
\hline 50006903 & $1,625,579$ & $1,769,065$ \\
\hline 53000303 & $1,638,133$ & $1,771,546$ \\
\hline 53000702 & $1,638,057$ & $1,771,054$ \\
\hline 55000415 & $1,624,870$ & $1,769,742$ \\
\hline 55000416 & $1,624,675$ & $1,769,550$ \\
\hline
\end{tabular}


Table 5. 40-61.94(b)(7) User-Supplied Data-Highest Off-Site Dose Location for Monitored Release Points

\begin{tabular}{|c|c|c|}
\hline ESIDNUM & $\begin{array}{l}\text { Distance to LANL Highest } \\
\text { Dose Location (m) }\end{array}$ & $\begin{array}{l}\text { Direction to LANL Highest } \\
\text { Dose Location }\end{array}$ \\
\hline 03002914 & 731 & $\mathrm{NE}$ \\
\hline 03002915 & 732 & $\mathrm{NE}$ \\
\hline 03002919 & 836 & NNE \\
\hline 03002920 & 835 & NNE \\
\hline 03002923 & 845 & $\mathrm{NE}$ \\
\hline 03002924 & 846 & $\mathrm{NE}$ \\
\hline 03002928 & 936 & $\mathrm{NE}$ \\
\hline 03002929 & 937 & $\mathrm{NE}$ \\
\hline 03002932 & 856 & NNE \\
\hline 03002933 & 855 & NNE \\
\hline 03002937 & 870 & $\mathrm{NE}$ \\
\hline 03002944 & 937 & NNE \\
\hline 03002945 & 939 & NNE \\
\hline 03002946 & 938 & NNE \\
\hline 03003501 & 691 & NNE \\
\hline 03010222 & 1,060 & $\mathrm{NE}$ \\
\hline 16020504 & 5,425 & $\mathrm{NE}$ \\
\hline 21015505 & 4,023 & W \\
\hline 21020901 & 4,095 & $\mathrm{~W}$ \\
\hline 33008606 & 11,933 & NNW \\
\hline 41000417 & 1,716 & $\mathrm{~W}$ \\
\hline 48000107 & 1,545 & NW \\
\hline 48000154 & 1,582 & NW \\
\hline 48000160 & 1,562 & NW \\
\hline 50000102 & 2,428 & NW \\
\hline 50003701 & 2,338 & NW \\
\hline 50006903 & 2,312 & NW \\
\hline 53000303 & 5,442 & $\mathrm{~W}$ \\
\hline 53000702 & 5,448 & WNW \\
\hline 55000415 & 2,015 & NW \\
\hline 55000416 & 2,022 & NW \\
\hline
\end{tabular}


Table 6. 40-61.94(b)(7) User-Supplied Data-Other Input Parameters

\begin{tabular}{lcccl}
\multicolumn{1}{c}{ Description } & Value & Units & $\begin{array}{c}\text { CAP88 Variable } \\
\text { Name }\end{array}$ & Reference \\
\hline Annual rainfall rate & 45.3 & $\mathrm{~cm} / \mathrm{y}$ & $\mathrm{RR}$ & Bowen (1990) \\
Lid height & 1525 & $\mathrm{~m}$ & LIPO & Holzworth (1972) \\
Annual median temp & 281.9 & $\mathrm{~K}$ & $\mathrm{TA}$ & Bowen (1990) \\
E-vertical temperature gradient & 0.02 & $\mathrm{~K} / \mathrm{m}$ & TG & EPA (1995) \\
F-vertical temperature gradient & 0.035 & $\mathrm{~K} / \mathrm{m}$ & TG & EPA (1995) \\
G-vertical temperature gradient & 0.035 & $\mathrm{~K} / \mathrm{m}$ & TG & EPA (1995) \\
Food supply fraction - local vegetables & 0.076 & & F1V & EPA (1989) \\
Food supply fraction - vegetable regional & 0.924 & & F2V & EPA (1989) \\
Food supply fraction - vegetable imported & 0 & & F3V & EPA (1989) \\
Food supply fraction - meat local & 0.008 & & F1B & EPA (1989) \\
Food supply fraction - meat regional & 0.992 & & F2B & EPA (1989) \\
Food supply fraction - meat imported & 0 & & F3B & EPA (1989) \\
Food supply fraction - milk local & 0 & & F1M & EPA (1989) \\
Food supply fraction - milk regional & 1 & F2M & EPA (1989) \\
Food supply fraction - milk imported & 0 & F3M & EPA (1989) \\
Ground surface roughness factor & 0.5 & GSCFAC & EPA (1989) \\
\hline
\end{tabular}

Brent M. Bowen, “Los Alamos Climatology,” Los Alamos National Laboratory report LA-11735-MS (1990).

George C. Holzworth, "Mixing Heights, Wind Speeds, and Potential for Urban Air Pollution throughout the Contiguous United States," U.S. Environmental Protection Agency Office of Air Programs report (1972).

U.S. Environmental Protection Agency, "User's Guide for the Industrial Source Complex (ISC3) Dispersion Models Volume II - Description of Model Algorithms," EPA-454/B-95-003b (1995).

U.S. Environmental Protection Agency, "Risk Assessments Methodology, Environmental Impact Statement, NESHAPS for Radionuclides, Background Information Document - Volume 1,” EPA/520/189-005 (1989). 
1999 LANL Radionuclide Air Emissions Report

Table 7. 40-61.94(b)(7) User-Supplied Data-Wind Frequency Arrays

$\underline{\text { CAP88 Input Data for } 1999 \text { TA-6 Meteorological Tower }}$

\begin{tabular}{|c|c|}
\hline 1 & 000950.000870 .000060 .000000 \\
\hline 2 & 0.001960 .001270 .000000 .000000 .000000 .00000 \\
\hline 3 & 0.003870 .001820 .000030 .000000 .000000 .00000 \\
\hline 4 & 0.007100 .004880 .000000 .000000 .000000 .00000 \\
\hline 5 & 0.008860 .006840 .000000 .000000 .000000 .00 \\
\hline 6 & 0.007880 .010270 .000000 .000000 .000000 .0 \\
\hline 7 & 360.013470 .000140 .000030 .000000 .00 \\
\hline 8 & 80.016700 .000460 .00 \\
\hline 9 & 70.008910 .000120 .00 \\
\hline 10 & .002 \\
\hline 1 & 0.000 \\
\hline 12 & 0.000 \\
\hline 13 & 50.000720 .00 \\
\hline 14 & 0.000 \\
\hline 15 & 0.000580 .000690 .000200 .00 \\
\hline 16 & 0.000660 .000690 .000170 .00 \\
\hline 1 & 0.000200 .000630 .000260 .00 \\
\hline 2 & 20.001240 .000260 .000000 .00 \\
\hline 3 & 50.002710 .000170 .000000 .00 \\
\hline 4 & 0.001670 .003840 .000140 .000000 .00 \\
\hline 5 & 0.001500 .004390 .000060 .000000 .00 \\
\hline 6 & 0.001130 .003060 .000030 .000000 .00 \\
\hline 7 & 0.000000 .000000 .0 \\
\hline 8 & 0.001470 .009200 .001150 .000060 .000000 .00000 \\
\hline 9 & 0.0 \\
\hline 10 & 0.000610 .004900 .004360 .000030 .000000 .00000 \\
\hline 11 & 0.000090 .000000 .00000 \\
\hline 12 & 0.000170 .001100 .001560 .000030 .000000 .00000 \\
\hline 13 & 0.000200 .0005 \\
\hline 14 & 0.000140 .000490 .000350 .000000 .0000 \\
\hline 15 & 0.000000 .000000 .00000 \\
\hline 16 & 0.000260 .000980 .000810 .000030 .000000 .00000 \\
\hline 1 & 0.000490 .0011 \\
\hline 2 & 0.001560 .003660 .001790 .000060 .000000 .00000 \\
\hline 3 & 0.001790 .000090 .0000 \\
\hline 4 & 0.001330 .006320 .000550 .000000 .000000 .00000 \\
\hline 5 & 0.001730 .004390 .000230 .000000 .000000 .00000 \\
\hline 6 & 0.001130 .002020 .000000 .000000 .000000 .00000 \\
\hline 7 & 0.000630 .000060 .000000 .000000 .00000 \\
\hline 8 & 0.001270 .006170 .001470 .000030 .000000 .00000 \\
\hline 9 & 0.001670 .018290 .016360 .000460 .000000 .00000 \\
\hline 10 & 0.001360 .010650 .013010 .001040 .000000 .00000 \\
\hline 11 & 0.000610 .004130 .005110 .000720 .000000 .00000 \\
\hline 12 & 0.000350 .002740 .006430 .000660 .000000 .00000 \\
\hline 13 & 0.000400 .001930 .004820 .000290 .000000 .00000 \\
\hline 14 & 0.000170 .001330 .003460 .000170 .000000 .00000 \\
\hline 15 & 0.000140 .002570 .004530 .000460 .000000 .00000 \\
\hline 16 & 0.000290 .001270 .000810 .000090 .000000 .00000 \\
\hline 1 & 0.003750 .006350 .000460 .000000 .000000 .00000 \\
\hline 2 & 0.004070 .008340 .002710 .000870 .000000 .00000 \\
\hline 3 & 0.003000 .005020 .000840 .000060 .000000 .00000 \\
\hline 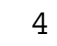 & 0.0032 \\
\hline
\end{tabular}


1999 LANL Radionuclide Air Emissions Report

Table 7. 40-61.94(b)(7) User-Supplied Data-Wind Frequency Arrays (continued)

(TA-6 data continued)

$$
\begin{aligned}
& 0.002830 .001470 .000030 .000000 .000000 .00000 \\
& 0.002830 .000720 .000030 .000000 .000000 .00000 \\
& 0.002570 .000520 .000060 .000000 .000000 .00000 \\
& 0.002860 .002310 .000350 .000320 .000000 .00000 \\
& 0.005710 .009870 .001700 .000260 .000000 .00000 \\
& 0.006350 .023050 .003810 .002080 .000060 .00000 \\
& 0.004530 .026600 .004820 .001440 .000260 .00000 \\
& 0.002940 .015550 .005160 .001820 .000230 .00000 \\
& 0.002310 .007070 .012610 .006920 .000780 .00006 \\
& 0.001790 .006980 .014800 .010990 .003980 .00101 \\
& 0.002390 .010180 .008630 .002970 .000870 .00003 \\
& 0.003090 .008370 .000870 .000170 .000000 .00000 \\
& 0.005400 .002970 .000000 .000000 .000000 .00000 \\
& 0.002910 .001850 .000000 .000000 .000000 .00000 \\
& 0.002160 .000890 .000000 .000000 .000000 .00000 \\
& 0.001180 .000260 .000000 .000000 .000000 .00000 \\
& 0.001010 .000140 .000000 .000000 .000000 .00000 \\
& 0.001070 .000030 .000000 .000000 .000000 .00000 \\
& 0.001330 .000030 .000000 .000000 .000000 .00000 \\
& 0.001880 .000090 .000000 .000000 .000000 .00000 \\
& 0.004210 .001040 .000000 .000000 .000000 .00000 \\
& 0.005190 .004470 .000000 .000000 .000000 .00000 \\
& 0.006200 .011140 .000000 .000000 .000000 .00000 \\
& 0.005450 .021720 .000200 .000000 .000000 .00000 \\
& 0.002970 .020510 .002080 .000000 .000000 .00000 \\
& 0.003290 .013390 .006260 .000090 .000000 .00000 \\
& 0.003400 .029310 .000630 .000000 .000000 .00000 \\
& 0.005250 .011970 .000000 .000000 .000000 .00000 \\
& 0.004730 .001040 .000000 .000000 .000000 .00000 \\
& 0.002770 .000430 .000000 .000000 .000000 .00000 \\
& 0.001330 .000030 .000000 .000000 .000000 .00000 \\
& 0.000920 .000000 .000000 .000000 .000000 .00000 \\
& 0.000690 .000000 .000000 .000000 .000000 .00000 \\
& 0.000630 .000000 .000000 .000000 .000000 .00000 \\
& 0.000810 .000000 .000000 .000000 .000000 .00000 \\
& 0.000870 .000000 .000000 .000000 .000000 .00000 \\
& 0.001880 .000000 .000000 .000000 .000000 .00000 \\
& 0.002940 .000430 .000000 .000000 .000000 .00000 \\
& 0.006150 .002220 .000000 .000000 .000000 .00000 \\
& 0.005890 .009610 .000000 .000000 .000000 .00000 \\
& 0.008420 .035080 .000140 .000000 .000000 .00000 \\
& 0.006720 .042560 .001640 .000000 .000000 .00000 \\
& 0.007590 .017430 .000000 .000000 .000000 .00000 \\
& 0.006780 .004270 .000000 .000000 .000000 .00000
\end{aligned}
$$


1999 LANL Radionuclide Air Emissions Report

Table 7. 40-61.94(b)(7) User-Supplied Data-Wind Frequency Arrays (continued)

$\underline{\text { CAP88 Input Data for } 1999 \text { TA-49 Meteorological Tower }}$
0.000180 .000030 .000000 .000000 .000000 .00000
0.000290 .000030 .000000 .000000 .000000 .00000
0.000650 .000120 .000000 .000000 .000000 .00000
0.000880 .000260 .000000 .000000 .000000 .00000
0.002320 .000210 .000000 .000000 .000000 .00000
0.001760 .000620 .000000 .000000 .000000 .00000
0.001670 .000650 .000000 .000000 .000000 .00000
0.000910 .000380 .000000 .000000 .000000 .00000
0.000560 .000290 .000000 .000000 .000000 .00000
0.000350 .000180 .000000 .000000 .000000 .00000
0.000230 .000000 .000000 .000000 .000000 .00000
0.000210 .000000 .000000 .000000 .000000 .00000
0.000290 .000030 .000000 .000000 .000000 .00000
0.000090 .000030 .000000 .000000 .000000 .00000
0.000000 .000030 .000030 .000000 .000000 .00000
0.000090 .000000 .000000 .000000 .000000 .00000
0.000030 .000030 .000000 .000000 .000000 .00000
0.000090 .000030 .000000 .000000 .000000 .00000
0.000150 .000150 .000000 .000000 .000000 .00000
0.000620 .000350 .000000 .000000 .000000 .00000
0.000880 .000940 .000000 .000000 .000000 .00000
0.000680 .000910 .000000 .000000 .000000 .00000
0.000380 .000820 .000000 .000000 .000000 .00000
0.000350 .000560 .000000 .000000 .000000 .00000
0.000320 .000560 .000000 .000000 .000000 .00000
0.000120 .000290 .000000 .000000 .000000 .00000
0.000000 .000180 .000000 .000000 .000000 .00000
0.000030 .000090 .000000 .000000 .000000 .00000
0.000120 .000000 .000000 .000000 .000000 .00000
0.000030 .000090 .000000 .000000 .000000 .00000
0.000120 .000030 .000000 .000000 .000000 .00000
0.000030 .000060 .000000 .000000 .000000 .00000
0.000120 .000090 .000000 .000000 .000000 .00000
0.000180 .000060 .000000 .000000 .000000 .00000
0.000440 .000320 .000000 .000000 .000000 .00000
0.000730 .000910 .000000 .000000 .000000 .00000
0.001380 .003960 .000000 .000000 .000000 .00000
0.001060 .004080 .000000 .000000 .000000 .00000
0.000700 .004790 .000000 .000000 .000000 .00000
0.000530 .002850 .000030 .000000 .000000 .00000
0.000320 .002550 .000000 .000000 .000000 .00000
0.000380 .001320 .000000 .000000 .000000 .00000
0.000210 .000530 .000030 .000000 .000000 .00000
0.000150 .000380 .000030 .000000 .000000 .00000
0.000150 .000350 .000030 .000000 .000000 .00000
0.000210 .000350 .000060 .000000 .000000 .00000
0.000060 .000230 .000000 .000000 .000000 .00000
0.000150 .000180 .000030 .000000 .000000 .00000
0.000880 .001350 .001560 .001140 .000000 .00000
0.000940 .001940 .001060 .002030 .000090 .00000
0.001230 .003350 .000650 .000970 .000000 .00000
0.002000 .006840 .000440 .000180 .000000 .00000 
1999 LANL Radionuclide Air Emissions Report

Table 7. 40-61.94(b)(7) User-Supplied Data-Wind Frequency Arrays (continued)

$\underline{\text { (TA-49 data continued) }}$

$$
\begin{aligned}
& 0.001590 .010510 .000650 .000030 .000000 .00000 \\
& 0.001290 .006810 .000680 .00000 .000000 .00000 \\
& 0.000940 .007980 .000470 .000500 .000320 .00003 \\
& 0.001120 .011390 .002970 .002320 .000530 .00023 \\
& 0.001200 .016090 .009070 .016350 .001850 .00003 \\
& 0.001000 .005990 .005720 .010540 .002520 .00044 \\
& 0.000680 .002520 .003380 .008430 .001350 .00073 \\
& 0.000910 .002380 .004140 .005340 .000820 .00012 \\
& 0.001120 .002990 .006340 .008220 .001000 .00023 \\
& 0.000790 .002320 .008660 .006610 .001610 .00012 \\
& 0.000790 .001470 .004490 .005340 .001760 .00018 \\
& 0.000970 .001320 .002610 .003380 .000500 .00012 \\
& 0.002550 .010360 .008220 .000210 .000000 .00000 \\
& 0.001730 .011040 .006310 .000290 .000000 .00000 \\
& 0.002110 .011800 .008510 .000560 .000000 .00000 \\
& 0.001730 .007490 .004080 .000090 .000000 .00000 \\
& 0.001260 .004400 .001350 .000030 .000000 .00000 \\
& 0.000880 .002260 .000680 .000030 .000000 .00000 \\
& 0.001000 .002550 .000880 .000090 .000000 .00000 \\
& 0.001320 .005550 .008220 .000620 .000000 .00000 \\
& 0.001610 .020780 .049230 .007020 .000000 .00000 \\
& 0.002760 .025100 .026710 .002910 .000000 .00000 \\
& 0.001670 .018820 .015180 .001000 .000000 .00000 \\
& 0.001560 .009160 .008780 .000560 .000000 .00000 \\
& 0.001670 .006870 .008720 .001230 .000000 .00000 \\
& 0.001670 .008190 .011770 .000730 .000000 .00000 \\
& 0.002200 .008510 .008950 .000560 .000000 .00000 \\
& 0.002140 .004700 .004290 .000380 .000000 .00000 \\
& 0.008190 .018850 .004490 .000000 .000000 .00000 \\
& 0.006020 .004290 .000230 .000000 .000000 .00000 \\
& 0.003850 .002640 .000530 .000000 .000000 .00000 \\
& 0.002170 .000590 .000120 .000000 .000000 .00000 \\
& 0.001140 .000380 .000000 .000000 .000000 .00000 \\
& 0.001470 .000350 .000000 .000000 .000000 .00000 \\
& 0.001610 .000790 .000090 .000000 .000000 .00000 \\
& 0.001910 .001170 .000260 .000000 .000000 .00000 \\
& 0.002500 .003460 .000500 .000000 .000000 .00000 \\
& 0.003880 .008370 .000590 .000000 .000000 .00000 \\
& 0.004730 .016670 .001290 .000000 .000000 .00000 \\
& 0.004610 .025420 .005280 .000000 .000000 .00000 \\
& 0.004960 .032640 .011100 .000000 .000000 .00000 \\
& 0.005200 .025220 .017440 .000000 .000000 .00000 \\
& 0.006520 .022870 .007930 .000000 .000000 .00000 \\
& 0.006660 .033440 .020080 .000060 .000000 .00000
\end{aligned}
$$


1999 LANL Radionuclide Air Emissions Report

Table 7. 40-61.94(b)(7) User-Supplied Data-Wind Frequency Arrays (continued)

$\underline{\text { CAP88 Input Data for } 1999 \text { TA-53 Meteorological Tower }}$

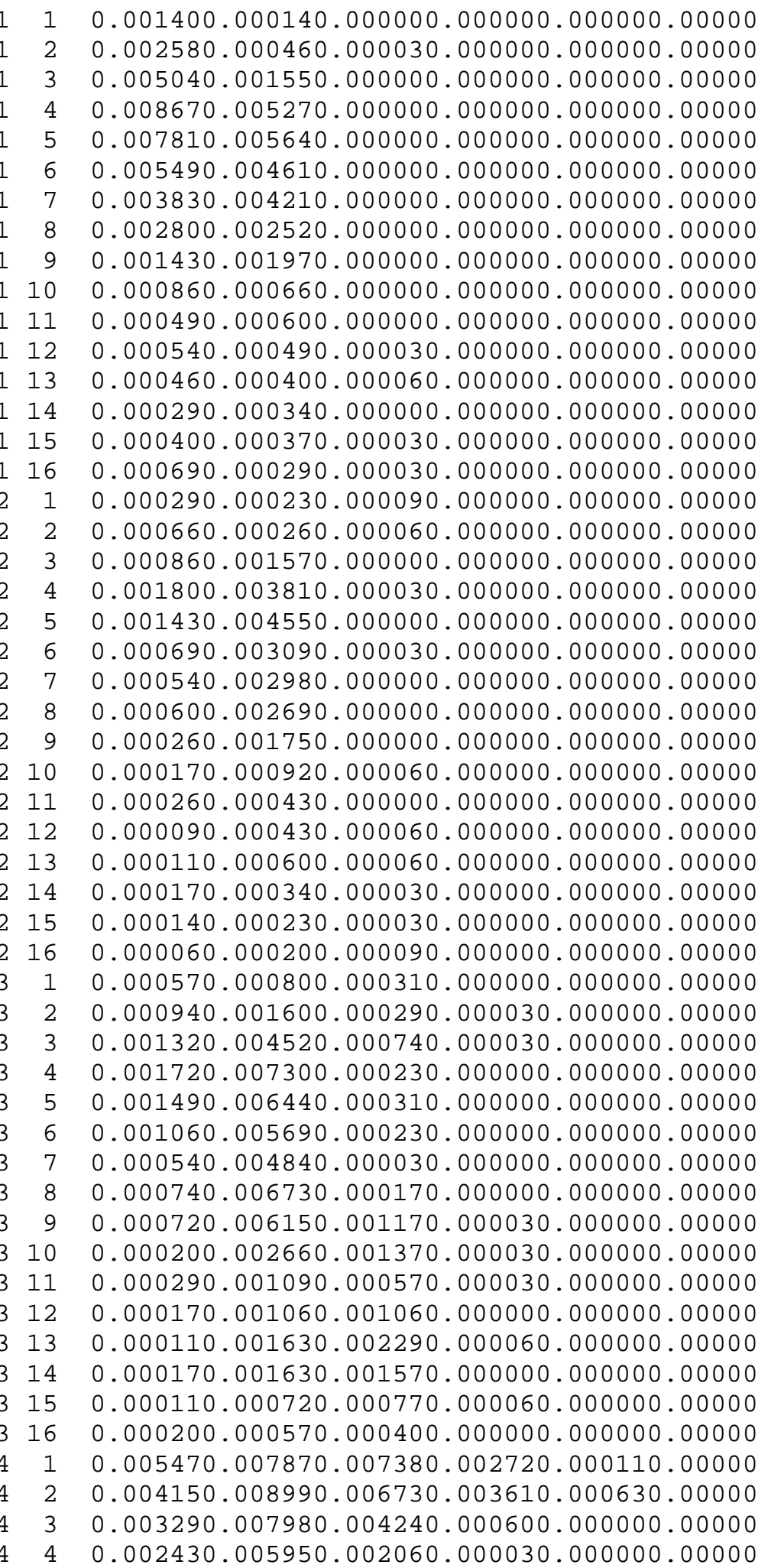


1999 LANL Radionuclide Air Emissions Report

Table 7. 40-61.94(b)(7) User-Supplied Data-Wind Frequency Arrays (continued)

$\underline{\text { (TA-53 data continued) }}$

\begin{tabular}{|c|c|}
\hline 5 & \\
\hline 6 & \\
\hline 1 & \\
\hline 8 & 001920.010190 .008010 .002290 .000600 .0001 \\
\hline 9 & 002170.015110 .029390 .012590 .000490 .0 \\
\hline 10 & 0.001830 .012360 .031620 .013710 .002 \\
\hline 11 & 0.001830 .014880 .020030 .007560 .000 \\
\hline 12 & 0.0017 \\
\hline 13 & 0.002260 .005900 .01 \\
\hline 14 & \\
\hline 15 & 10.00 \\
\hline 16 & \\
\hline 1 & 0.00 \\
\hline 2 & \\
\hline 3 & 0.0 \\
\hline 4 & \\
\hline 5 & 0.0 \\
\hline 6 & \\
\hline 7 & 0.0 \\
\hline 8 & 0.0 \\
\hline 9 & \\
\hline 10 & 0. \\
\hline 11 & \\
\hline 12 & 0 \\
\hline 13 & \\
\hline 14 & 0. \\
\hline 15 & \\
\hline 16 & 0 \\
\hline 1 & 0 . \\
\hline 2 & 0.0 \\
\hline 3 & \\
\hline 4 & 0.0 \\
\hline 5 & \\
\hline 6 & 0.0 \\
\hline 7 & 0.0 \\
\hline 8 & 0.0 \\
\hline 9 & 0.0 \\
\hline 10 & .00000 \\
\hline 11 & 0.002 \\
\hline 12 & .000830 .000000 .0000 \\
\hline 13 & 0.000000 .0000 \\
\hline 14 & 0.0020 \\
\hline 15 & 0.0 \\
\hline & \\
\hline
\end{tabular}


1999 LANL Radionuclide Air Emissions Report

Table 7. 40-61.94(b)(7) User-Supplied Data-Wind Frequency Arrays (continued)

$\underline{\text { CAP88 Input Data for } 1999 \text { TA-54 Meteorological Tower }}$

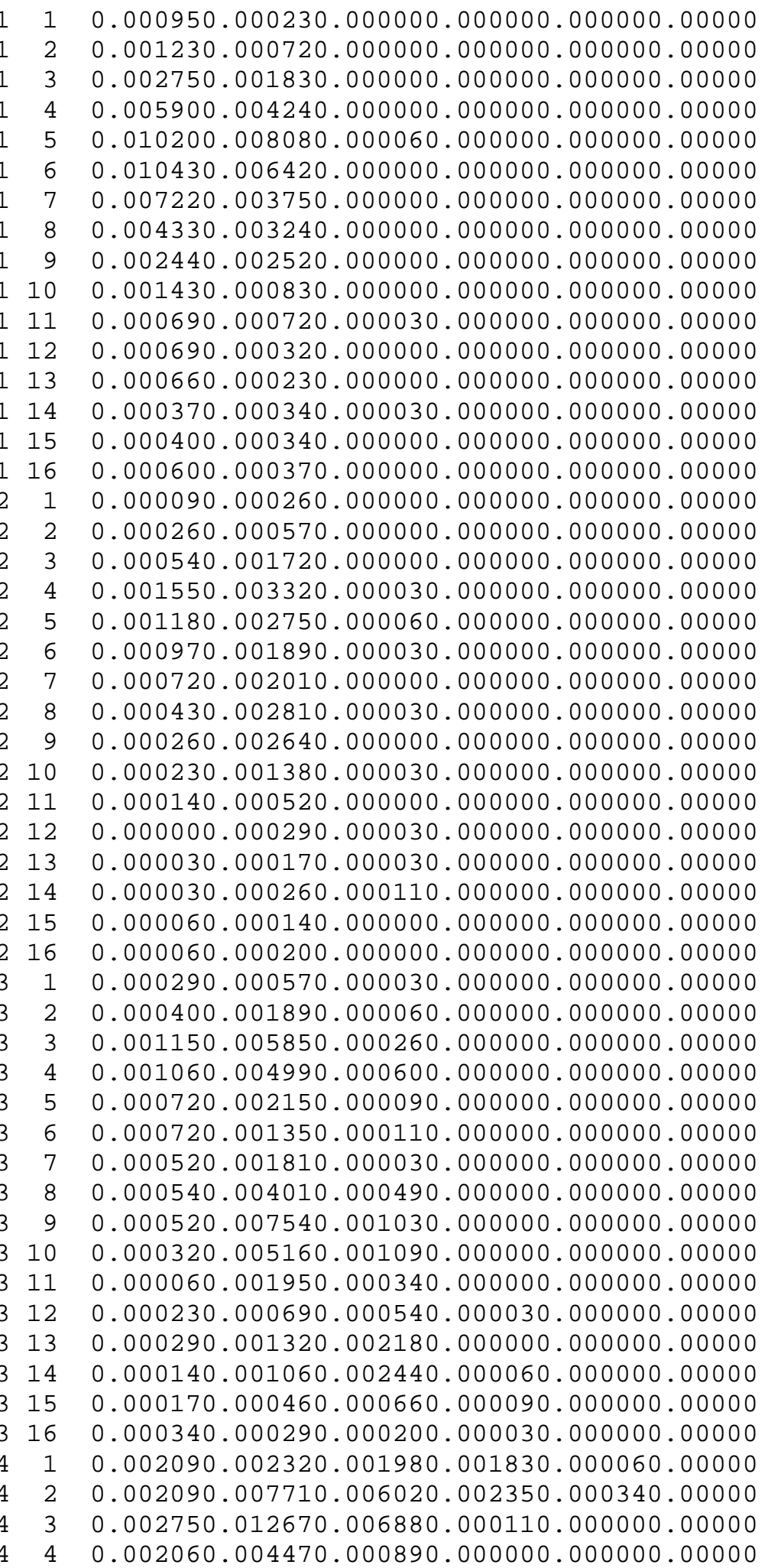


1999 LANL Radionuclide Air Emissions Report

Table 7. 40-61.94(b)(7) User-Supplied Data-Wind Frequency Arrays (continued)

$\underline{\text { (TA-54 data continued) }}$

$$
\begin{aligned}
& 0.001600 .001180 .000000 .000000 .000000 .00000 \\
& 0.001550 .000230 .000000 .000030 .000000 .00000 \\
& 0.001120 .001290 .000370 .000090 .000000 .00000 \\
& 0.001580 .003300 .004240 .002410 .000460 .00000 \\
& 0.001490 .009570 .019860 .009430 .000430 .00000 \\
& 0.001430 .013500 .041130 .019690 .002720 .00023 \\
& 0.001000 .006100 .011660 .007740 .001030 .00020 \\
& 0.001260 .004590 .006790 .003470 .000430 .00000 \\
& 0.001200 .003960 .009290 .002440 .000340 .00000 \\
& 0.001750 .003810 .008110 .001810 .000030 .00000 \\
& 0.001180 .003120 .005360 .001810 .000090 .00000 \\
& 0.001660 .001810 .001890 .001180 .000230 .00000 \\
& 0.006390 .006760 .003840 .000140 .000000 .00000 \\
& 0.003610 .008540 .005790 .000200 .000000 .00000 \\
& 0.003380 .005300 .001200 .000000 .000000 .00000 \\
& 0.002520 .001600 .000090 .000000 .000000 .00000 \\
& 0.001260 .000230 .000000 .000000 .000000 .00000 \\
& 0.000970 .000000 .000000 .000000 .000000 .00000 \\
& 0.000860 .000400 .000030 .000000 .000000 .00000 \\
& 0.001030 .000830 .000110 .000000 .000000 .00000 \\
& 0.001150 .003870 .001090 .000060 .000000 .00000 \\
& 0.001830 .013960 .019570 .001400 .000000 .00000 \\
& 0.002060 .017830 .022440 .000370 .000000 .00000 \\
& 0.002720 .011550 .002610 .000000 .000000 .00000 \\
& 0.003840 .017020 .001580 .000000 .000000 .00000 \\
& 0.006680 .020350 .001810 .000000 .000000 .00000 \\
& 0.008480 .028570 .001120 .000000 .000000 .00000 \\
& 0.011350 .014100 .001720 .000090 .000000 .00000 \\
& 0.007390 .009090 .000230 .000000 .000000 .00000 \\
& 0.006360 .005850 .000320 .000000 .000000 .00000 \\
& 0.003010 .003380 .000030 .000000 .000000 .00000 \\
& 0.001350 .000370 .000000 .000000 .000000 .00000 \\
& 0.000400 .000000 .000000 .000000 .000000 .00000 \\
& 0.000540 .000000 .000000 .000000 .000000 .00000 \\
& 0.000400 .000030 .000000 .000000 .000000 .00000 \\
& 0.000230 .000110 .000000 .000000 .000000 .00000 \\
& 0.000770 .000630 .000030 .000000 .000000 .00000 \\
& 0.001890 .004160 .000340 .000000 .000000 .00000 \\
& 0.002550 .013700 .002410 .000000 .000000 .00000 \\
& 0.003840 .023300 .004500 .000000 .000000 .00000 \\
& 0.008710 .032440 .002780 .000000 .000000 .00000 \\
& 0.016420 .024620 .000030 .000000 .000000 .00000 \\
& 0.015450 .037520 .000430 .000000 .000000 .00000 \\
& 0.010520 .016050 .001350 .000000 .000000 .00000
\end{aligned}
$$


Table 8. 40-61.94(b)(7) User-supplied Data-Population Array

Projected 1999 Population within $80 \mathrm{~km}$ of Los Alamos National Laboratory

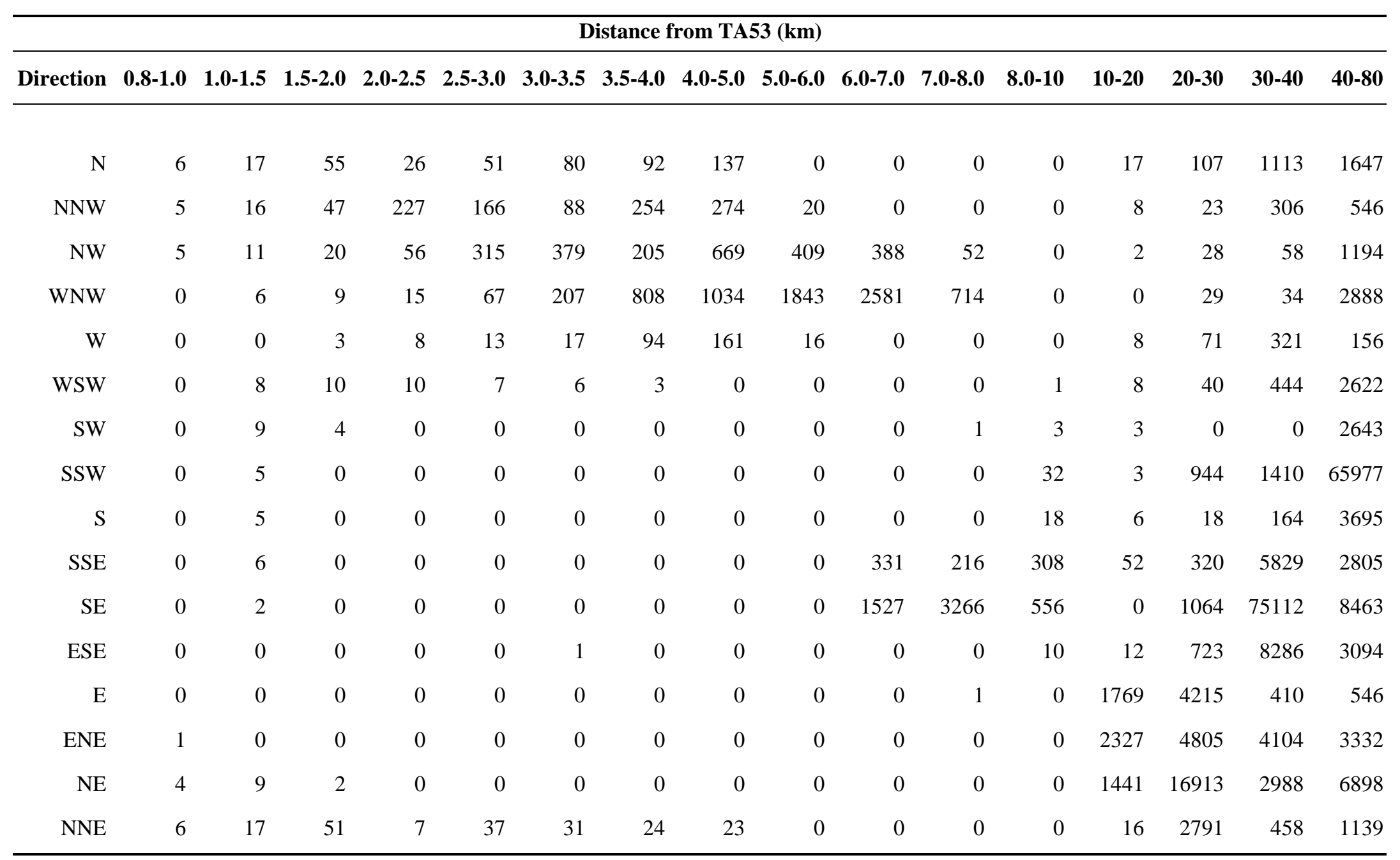


Table 9. 40-61.94(b)(7) User-Supplied Data-Radionuclide Emissions

\begin{tabular}{|c|c|c|}
\hline ESIDNUM & Nuclide & $\operatorname{Emission}(\mathbf{C i})$ \\
\hline 03002914 & Th-230 & $9.54 \mathrm{e}-09$ \\
\hline 03002915 & $\mathrm{Pu}-239$ & $1.36 \mathrm{e}-08$ \\
\hline 03002915 & U-238 & $1.57 \mathrm{e}-08$ \\
\hline 03002915 & Th-234 & $1.57 \mathrm{e}-08$ \\
\hline 03002915 & $\mathrm{~Pa}-234 \mathrm{~m}$ & $1.57 \mathrm{e}-08$ \\
\hline 03002919 & Am-241 & $2.37 \mathrm{e}-06$ \\
\hline 03002919 & $\mathrm{Pu}-238$ & $2.16 \mathrm{e}-06$ \\
\hline 03002919 & $\mathrm{Pu}-239$ & $1.80 \mathrm{e}-05$ \\
\hline 03002919 & U-234 & $1.02 \mathrm{e}-08$ \\
\hline 03002920 & Am-241 & $1.66 \mathrm{e}-07$ \\
\hline 03002920 & $\mathrm{Pu}-238$ & $1.51 \mathrm{e}-08$ \\
\hline 03002920 & $\mathrm{Pu}-239$ & $4.10 \mathrm{e}-07$ \\
\hline 03002923 & Pu-239 & $3.20 \mathrm{e}-08$ \\
\hline 03002923 & Tc-99 & $9.22 \mathrm{e}-04$ \\
\hline 03002923 & Th-230 & $2.12 \mathrm{e}-08$ \\
\hline 03002923 & U-238 & $9.01 \mathrm{e}-08$ \\
\hline 03002923 & Th-234 & $9.01 \mathrm{e}-08$ \\
\hline 03002923 & $\mathrm{~Pa}-234 \mathrm{~m}$ & $9.01 \mathrm{e}-08$ \\
\hline 03002923 & U-234 & $2.94 \mathrm{e}-06$ \\
\hline 03002923 & U-235 & $9.74 \mathrm{e}-08$ \\
\hline 03002923 & Th-231 & $9.74 \mathrm{e}-08$ \\
\hline 03002924 & Am-241 & $1.33 \mathrm{e}-08$ \\
\hline 03002924 & $\mathrm{Pu}-238$ & $5.02 \mathrm{e}-08$ \\
\hline 03002924 & $\mathrm{Pu}-239$ & $3.23 \mathrm{e}-08$ \\
\hline 03002924 & Th-228 & $1.16 \mathrm{e}-07$ \\
\hline 03002924 & Th-230 & $3.36 \mathrm{e}-08$ \\
\hline 03002924 & U-234 & $2.86 \mathrm{e}-06$ \\
\hline 03002924 & U-235 & $4.06 \mathrm{e}-09$ \\
\hline 03002924 & Th-231 & $4.06 \mathrm{e}-09$ \\
\hline 03002928 & $\mathrm{Pu}-238$ & $3.87 \mathrm{e}-08$ \\
\hline 03002928 & U-234 & $1.68 \mathrm{e}-08$ \\
\hline 03002929 & Am-241 & $2.36 \mathrm{e}-08$ \\
\hline 03002929 & $\mathrm{Pu}-238$ & $1.27 \mathrm{e}-08$ \\
\hline 03002929 & $\mathrm{Pu}-239$ & $2.42 \mathrm{e}-07$ \\
\hline 03002929 & Th-230 & $2.56 \mathrm{e}-08$ \\
\hline 03002929 & U-234 & $2.08 \mathrm{e}-08$ \\
\hline 03002932 & None detected & None \\
\hline 03002933 & U-234 & $1.59 \mathrm{e}-08$ \\
\hline 03002937 & $\mathrm{U}-234$ & $5.93 e-10$ \\
\hline 03002944 & U-234 & $2.16 \mathrm{e}-08$ \\
\hline
\end{tabular}


Table 9. 40-61.94(b)(7) User-Supplied Data-Radionuclide Emissions (continued)

\begin{tabular}{|c|c|c|}
\hline ESIDNUM & Nuclide & $\operatorname{Emission}(\mathbf{C i})$ \\
\hline 03002945 & None detected & None \\
\hline 03002946 & U-234 & $1.53 \mathrm{e}-08$ \\
\hline 03003501 & Th-230 & $6.43 e-09$ \\
\hline 03003501 & $\mathrm{U}-235$ & $4.55 \mathrm{e}-08$ \\
\hline 03003501 & Th-231 & $4.55 \mathrm{e}-08$ \\
\hline 03003501 & $\mathrm{U}-238$ & $1.33 \mathrm{e}-08$ \\
\hline 03003501 & Th-234 & $1.33 \mathrm{e}-08$ \\
\hline 03003501 & $\mathrm{~Pa}-234 \mathrm{~m}$ & $1.33 \mathrm{e}-08$ \\
\hline 03003501 & $\mathrm{U}-234$ & $1.18 \mathrm{e}-06$ \\
\hline 03010222 & Th-228 & $2.52 \mathrm{e}-09$ \\
\hline 03010222 & Th-230 & $7.80 \mathrm{e}-10$ \\
\hline 03010222 & U-235 & $1.17 \mathrm{e}-08$ \\
\hline 03010222 & Th-231 & $1.17 \mathrm{e}-08$ \\
\hline 03010222 & Th-232 & $5.42 \mathrm{e}-10$ \\
\hline 03010222 & U-238 & $1.33 \mathrm{e}-08$ \\
\hline 03010222 & Th-234 & $1.33 \mathrm{e}-08$ \\
\hline 03010222 & $\mathrm{~Pa}-234 \mathrm{~m}$ & $1.33 \mathrm{e}-08$ \\
\hline 03010222 & U-234 & $3.00 \mathrm{e}-07$ \\
\hline 16020504 & $\mathrm{H}-3$ & $1.37 e+02$ \\
\hline 16020504 & $\mathrm{H}-3$ & $2.44 \mathrm{e}+01$ \\
\hline 21015505 & $\mathrm{H}-3$ & $1.69 \mathrm{e}+01$ \\
\hline 21015505 & $\mathrm{H}-3$ & $4.89 \mathrm{e}+01$ \\
\hline 21020901 & $\mathrm{H}-3$ & $3.28 \mathrm{e}+02$ \\
\hline 21020901 & $\mathrm{H}-3$ & $9.23 e+01$ \\
\hline 33008606 & $\mathrm{H}-3$ & $2.28 \mathrm{e}+02$ \\
\hline 33008606 & $\mathrm{H}-3$ & $7.12 \mathrm{e}+02$ \\
\hline 41000417 & $\mathrm{H}-3$ & $1.11 \mathrm{e}+01$ \\
\hline 41000417 & $\mathrm{H}-3$ & $1.47 \mathrm{e}+00$ \\
\hline 48000107 & As-73 & $1.83 e-05$ \\
\hline 48000107 & As-74 & $4.49 \mathrm{e}-05$ \\
\hline 48000107 & $\mathrm{Br}-77$ & $1.15 \mathrm{e}-05$ \\
\hline 48000107 & Ga-68 & $1.71 \mathrm{e}-03$ \\
\hline 48000107 & Ge-68 & $1.71 \mathrm{e}-03$ \\
\hline 48000107 & $\mathrm{Se}-75$ & $3.50 \mathrm{e}-04$ \\
\hline 48000154 & None detected & None \\
\hline 48000160 & Ga-68 & $1.54 \mathrm{e}-05$ \\
\hline 48000160 & Ge-68 & $1.54 \mathrm{e}-05$ \\
\hline 48000160 & P-32 & $5.07 e-06$ \\
\hline 48000160 & $\mathrm{Si}-32$ & $5.07 \mathrm{e}-06$ \\
\hline 48000160 & U-238 & $6.05 \mathrm{e}-10$ \\
\hline
\end{tabular}


Table 9. 40-61.94(b)(7) User-Supplied Data-Radionuclide Emissions (continued)

\begin{tabular}{|c|c|c|}
\hline ESIDNUM & Nuclide & $\operatorname{Emission}(\mathbf{C i})$ \\
\hline 48000160 & Th-234 & $6.05 \mathrm{e}-10$ \\
\hline 48000160 & $\mathrm{~Pa}-234 \mathrm{~m}$ & $6.05 \mathrm{e}-10$ \\
\hline 50000102 & Am-241 & $1.31 \mathrm{e}-07$ \\
\hline 50000102 & $\mathrm{Pu}-238$ & $3.38 \mathrm{e}-08$ \\
\hline 50000102 & $\mathrm{Pu}-239$ & $1.76 \mathrm{e}-08$ \\
\hline 50000102 & Th-230 & $3.72 \mathrm{e}-08$ \\
\hline 50003701 & U-238 & $2.30 \mathrm{e}-09$ \\
\hline 50003701 & Th-234 & $2.30 \mathrm{e}-09$ \\
\hline 50003701 & $\mathrm{~Pa}-234 \mathrm{~m}$ & $2.30 \mathrm{e}-09$ \\
\hline 50003701 & U-234 & $1.68 \mathrm{e}-08$ \\
\hline 50006903 & $\mathrm{Pu}-238$ & $9.94 \mathrm{e}-11$ \\
\hline 53000303 & Ar-41 & $1.50 \mathrm{e}-01$ \\
\hline 53000303 & $\mathrm{C}-11$ & $4.11 \mathrm{e}+00$ \\
\hline 53000303 & $\mathrm{H}-3$ & $1.80 \mathrm{e}+00$ \\
\hline 53000702 & Ar-41 & $1.29 \mathrm{e}+01$ \\
\hline 53000702 & $\mathrm{Br}-76$ & $2.32 \mathrm{e}-04$ \\
\hline 53000702 & $\mathrm{Br}-82$ & $6.27 \mathrm{e}-04$ \\
\hline 53000702 & $\mathrm{C}-10$ & $4.24 \mathrm{e}-02$ \\
\hline 53000702 & C-11 & $2.62 \mathrm{e}+02$ \\
\hline 53000702 & Co-60 & $3.97 e-06$ \\
\hline 53000702 & $\mathrm{H}-3$ & $4.46 \mathrm{e}-01$ \\
\hline 53000702 & Hg-197 & $1.60 \mathrm{e}-03$ \\
\hline 53000702 & $\mathrm{~N}-13$ & $1.59 \mathrm{e}+00$ \\
\hline 53000702 & $\mathrm{~N}-16$ & $1.50 \mathrm{e}-02$ \\
\hline 53000702 & O-14 & $1.00 \mathrm{e}-01$ \\
\hline 53000702 & O-15 & $1.89 \mathrm{e}+01$ \\
\hline 55000415 & Am-241 & $5.39 \mathrm{e}-08$ \\
\hline 55000415 & $\mathrm{Pu}-239$ & $4.72 \mathrm{e}-08$ \\
\hline 55000415 & U-238 & $2.99 \mathrm{e}-08$ \\
\hline 55000415 & Th-234 & $2.99 \mathrm{e}-08$ \\
\hline 55000415 & $\mathrm{~Pa}-234 \mathrm{~m}$ & $2.99 \mathrm{e}-08$ \\
\hline 55000416 & $\mathrm{H}-3$ & $1.45 \mathrm{e}+00$ \\
\hline 55000416 & $\mathrm{H}-3$ & $3.09 \mathrm{e}-01$ \\
\hline 55000416 & $\mathrm{Pu}-239$ & $1.60 \mathrm{e}-08$ \\
\hline 55000416 & $\mathrm{U}-238$ & $2.14 \mathrm{e}-08$ \\
\hline 55000416 & Th-234 & $2.14 \mathrm{e}-08$ \\
\hline 55000416 & $\mathrm{~Pa}-234 \mathrm{~m}$ & $2.14 \mathrm{e}-08$ \\
\hline 55000416 & $\mathrm{U}-234$ & $1.97 \mathrm{e}-08$ \\
\hline
\end{tabular}


Table 10. 40-61.94(b)(7) User-Supplied Data-Modeling Parameters for LANL Non-Point Sources LANL Air Activation Sources

\begin{tabular}{lccccc}
\hline Source & Radionuclide & $\begin{array}{c}\text { Emissions } \\
(\mathbf{C i})\end{array}$ & $\begin{array}{c}\text { Area of } \\
\text { Source } \\
\left(\mathbf{m}^{2}\right)\end{array}$ & $\begin{array}{c}\text { Distance to } \\
\text { LANL } \\
\text { Maximum } \\
\text { Dose Location } \\
(\mathbf{m})\end{array}$ & $\begin{array}{c}\text { Direction } \\
\text { to LANL } \\
\text { Maximum } \\
\text { Dose } \\
\text { Location }\end{array}$ \\
\hline \multirow{2}{*}{ TA-53-Switchyard } & Ar-41 & 0.7 & 484 & 5,420 & $\mathrm{~W}$ \\
& $\mathrm{C}-11$ & 17.1 & 484 & 5,420 & $\mathrm{~W}$ \\
TA-18 & Ar-41 & 0.49 & 31,400 & 5,865 & $\mathrm{NW}$ \\
\hline \hline
\end{tabular}

Table 11. 40-61.94(b)(7) User-Supplied Data-Radionuclides Not Included in CAP88

\begin{tabular}{|c|c|c|c|c|c|}
\hline Source & ESIDNUM & Radionuclide & $\begin{array}{l}\text { Emissions } \\
\quad(\mathbf{C i})\end{array}$ & $\begin{array}{c}\text { Dose at LANL } \\
\text { Receptor } \\
\text { (mrem) }\end{array}$ & $\begin{array}{c}\text { Dose at Facility } \\
\text { Receptor } \\
\text { (mrem) }\end{array}$ \\
\hline \multirow[t]{6}{*}{ TA-48-1-7 } & 48000107 & As-73 & $1.83 \mathrm{E}-05$ & $1.36 \mathrm{E}-07$ & $1.45 \mathrm{E}-06$ \\
\hline & & As-74 & $4.49 \mathrm{E}-05$ & $1.68 \mathrm{E}-06$ & $1.82 \mathrm{E}-05$ \\
\hline & & $\mathrm{Br}-77$ & $1.15 \mathrm{E}-05$ & $2.26 \mathrm{E}-08$ & 2.38E-07 \\
\hline & & $\mathrm{Ga}-68$ & $1.71 \mathrm{E}-03$ & $1.54 \mathrm{E}-07$ & $1.65 \mathrm{E}-06$ \\
\hline & & $\mathrm{Ge}-68$ & $1.71 \mathrm{E}-03$ & $7.00 \mathrm{E}-04$ & $7.50 \mathrm{E}-03$ \\
\hline & & Se-75 & $3.50 \mathrm{E}-04$ & $1.71 \mathrm{E}-04$ & $1.88 \mathrm{E}-03$ \\
\hline \multirow[t]{3}{*}{ TA48-1-60 } & 48000160 & Ga-68 & $1.54 \mathrm{E}-05$ & $1.43 \mathrm{E}-09$ & $1.54 \mathrm{E}-08$ \\
\hline & & Ge-68 & $1.54 \mathrm{E}-05$ & $6.50 \mathrm{E}-06$ & $7.00 \mathrm{E}-05$ \\
\hline & & $\mathrm{Si}-32$ & $5.07 \mathrm{E}-06$ & $1.39 \mathrm{E}-05$ & $1.52 \mathrm{E}-04$ \\
\hline \multirow[t]{5}{*}{ TA-53-7-2 } & 53000702 & $\mathrm{Br}-76$ & $2.32 \mathrm{e}-04$ & $3.17 \mathrm{E}-08$ & $1.46 \mathrm{E}-06$ \\
\hline & & $\mathrm{C}-10^{*}$ & $4.24 \mathrm{E}-02$ & $2.06 \mathrm{E}-22$ & $1.58 \mathrm{E}-08$ \\
\hline & & $\mathrm{Hg}-197$ & $1.60 \mathrm{e}-03$ & $5.82 \mathrm{E}-07$ & $2.75 \mathrm{E}-05$ \\
\hline & & $\mathrm{N}-16^{*}$ & $1.50 \mathrm{E}-02$ & $0.00 \mathrm{E}-00$ & $1.19 \mathrm{E}-12$ \\
\hline & & $\mathrm{O}-14^{*}$ & $1.00 \mathrm{E}-01$ & $2.75 \mathrm{E}-11$ & $1.75 \mathrm{E}-03$ \\
\hline
\end{tabular}

"As discussed in Section III of this report under the subheading "Radionuclides Not Included in CAP88," the Air Quality group has added these radionuclides to the CAP88 database. 
Table 12. 40-61.94(b)(7) User-Supplied Data-Supplemental Dose Factors

\begin{tabular}{ccc} 
Radionuclide & Ci per m $^{\mathbf{3}}$ per $\mathbf{1 0}$ mrem & Reference \\
\hline As-73 & $1.10 \mathrm{E}-11$ & EPA (1989) \\
As-74 & $2.20 \mathrm{E}-12$ & EPA (1989) \\
Br-76 & $1.23 \mathrm{E}-10$ & LANL (2000) \\
Br-77 & $4.20 \mathrm{E}-11$ & EPA (1989) \\
C-10 & $1.13 \mathrm{E}-11$ & DOE/LANL (1998) \\
Ga-68 & $9.10 \mathrm{E}-10$ & LANL(2000) \\
Ge-68 & $2.00 \mathrm{E}-13$ & LANL(2000) \\
Hg-197 & $8.30 \mathrm{E}-11$ & EPA (1989) \\
N-16 & $3.43 \mathrm{E}-12$ & DOE/LANL (1998) \\
O-14 & $5.29 \mathrm{E}-12$ & DOE/LANL (1998) \\
Se-75 & $1.70 \mathrm{E}-13$ & EPA (1989) \\
Si-32 & $3.40 \mathrm{E}-14$ & LANL (2000) \\
\hline
\end{tabular}

Department of Energy, letter to Mr. George P. Brozowski, U.S. Environmental Protection Agency Region 6 from Mr. Steve Fong, DOE Los Alamos Area Office, Aug 18, 1998.

Los Alamos National Laboratory, internal memo to Mr. Scott Miller from Keith W. Jacobson, Air Quality Group memo ESH17:900-260, April 28, 2000.

U.S. Environmental Protection Agency, "National Emission Standards for Emissions of Radionuclides other than Radon from Department of Energy Facilities," Code of Federal Regulations, Title 40, Part 61.90, Table 2 of Appendix E to Subpart H (1989). 
Table 13. FFCA Environmental Data

1999 Effective Dose Equivalent (net in mrem) at Air Sampling Locations Around LANL

\begin{tabular}{llllllllll}
\hline \hline Site \# and Name & Am-241 & H-3 & Pu-238 & Pu-239 & U-234 & U-235 & $\begin{array}{c}\text { U-238 } \\
\text { Rounded } \\
\text { Total }\end{array}$ \\
\hline 06 & & & & & & & & & \\
07 & 48th Street & 0.008 & 0.004 & 0.000 & 0.002 & 0.000 & 0.001 & 0.000 & 0.02 \\
08 & LA McDonalds & 0.006 & 0.008 & 0.002 & 0.034 & 0.038 & 0.003 & 0.033 & 0.12 \\
09 & Los Alamos Airport & 0.006 & 0.016 & -0.001 & -0.001 & 0.005 & 0.000 & 0.006 & 0.03 \\
10 & East Gate & 0.005 & 0.023 & 0.000 & 0.006 & 0.003 & 0.001 & 0.004 & 0.04 \\
11 & Well PM-1 (E. Jemez Road) & 0.005 & 0.024 & 0.000 & 0.003 & 0.006 & 0.001 & 0.008 & 0.05 \\
12 & Royal Crest Trailer Court & -0.002 & 0.012 & 0.001 & 0.003 & 0.002 & 0.001 & 0.001 & 0.02 \\
13 & Rocket Park & 0.001 & 0.010 & 0.003 & 0.000 & 0.007 & 0.000 & 0.010 & 0.03 \\
14 & Pajarito Acres & 0.004 & 0.022 & 0.001 & 0.000 & 0.003 & 0.001 & 0.003 & 0.03 \\
15 & White Rock Fire Station & 0.004 & 0.014 & 0.000 & 0.001 & 0.002 & 0.001 & 0.006 & 0.03 \\
16 & White Rock Nazarene Church & 0.004 & 0.013 & 0.001 & 0.001 & 0.007 & 0.002 & 0.008 & 0.04 \\
20 & TA-21 Area B & 0.001 & 0.022 & 0.000 & 0.002 & 0.004 & 0.001 & 0.004 & 0.03 \\
32 & County Landfill & 0.029 & 0.000 & 0.005 & 0.012 & 0.001 & 0.011 & 0.06 \\
60 & LA Canyon & 0.033 & 0.013 & 0.001 & 0.017 & 0.067 & 0.003 & 0.062 & 0.20 \\
61 & LA Hospital & 0.004 & 0.009 & 0.001 & 0.003 & 0.007 & 0.002 & 0.006 & 0.03 \\
62 & Crossroads Bible Church & 0.004 & 0.007 & 0.001 & 0.006 & 0.016 & 0.002 & 0.013 & 0.05 \\
63 & Monte Rey South & 0.002 & 0.012 & 0.001 & 0.001 & 0.003 & 0.001 & 0.004 & 0.02 \\
& & 0.002 & 0.014 & 0.002 & 0.002 & 0.004 & 0.001 & 0.007 & 0.03 \\
\hline
\end{tabular}


Table 14. FFCA Analytical Completeness Summary-Air Sampler Operation

\begin{tabular}{|c|c|c|c|c|}
\hline Site \# & Site Name & $\begin{array}{l}\% \text { Run } \\
\text { Time }\end{array}$ & Analysis & $\begin{array}{l}\% \text { Analytical } \\
\text { Completeness }\end{array}$ \\
\hline \multirow[t]{8}{*}{06} & 48th Street & 99.8 & & \\
\hline & & & Am-241 & 100.0 \\
\hline & & & $\mathrm{H}-3$ & 100.0 \\
\hline & & & $\mathrm{Pu}-238$ & 100.0 \\
\hline & & & $\mathrm{Pu}-239$ & 100.0 \\
\hline & & & U-234 & 100.0 \\
\hline & & & $\mathrm{U}-235$ & 100.0 \\
\hline & & & $\mathrm{U}-238$ & 100.0 \\
\hline \multirow[t]{8}{*}{07} & Gulf/Exxon/Shell Station & 98.9 & & \\
\hline & & & Am-241 & 100.0 \\
\hline & & & $\mathrm{H}-3$ & 100.0 \\
\hline & & & $\mathrm{Pu}-238$ & 100.0 \\
\hline & & & $\mathrm{Pu}-239$ & 100.0 \\
\hline & & & U-234 & 100.0 \\
\hline & & & U-235 & 100.0 \\
\hline & & & $\mathrm{U}-238$ & 100.0 \\
\hline \multirow[t]{8}{*}{08} & McDonalds & 100.3 & & \\
\hline & & & Am-241 & 100.0 \\
\hline & & & $\mathrm{H}-3$ & 100.0 \\
\hline & & & $\mathrm{Pu}-238$ & 100.0 \\
\hline & & & $\mathrm{Pu}-239$ & 100.0 \\
\hline & & & U-234 & 100.0 \\
\hline & & & $\mathrm{U}-235$ & 100.0 \\
\hline & & & $\mathrm{U}-238$ & 100.0 \\
\hline \multirow[t]{8}{*}{09} & Los Alamos Airport & 100.1 & & \\
\hline & & & Am-241 & 100.0 \\
\hline & & & $\mathrm{H}-3$ & 100.0 \\
\hline & & & $\mathrm{Pu}-238$ & 100.0 \\
\hline & & & $\mathrm{Pu}-239$ & 100.0 \\
\hline & & & U-234 & 100.0 \\
\hline & & & U-235 & 100.0 \\
\hline & & & U-238 & 100.0 \\
\hline \multirow[t]{8}{*}{10} & Eastgate & 99.8 & & \\
\hline & & & Am-241 & 100.0 \\
\hline & & & $\mathrm{H}-3$ & 100.0 \\
\hline & & & $\mathrm{Pu}-238$ & 100.0 \\
\hline & & & $\mathrm{Pu}-239$ & 100.0 \\
\hline & & & $\mathrm{U}-234$ & 100.0 \\
\hline & & & $\mathrm{U}-235$ & 100.0 \\
\hline & & & $\mathrm{U}-238$ & 100.0 \\
\hline \multirow[t]{8}{*}{11} & Well PM-1 (E. Jemez Road) & 100.0 & & \\
\hline & & & Am-241 & 100.0 \\
\hline & & & $\mathrm{H}-3$ & 100.0 \\
\hline & & & $\mathrm{Pu}-238$ & 100.0 \\
\hline & & & $\mathrm{Pu}-239$ & 100.0 \\
\hline & & & $\mathrm{U}-234$ & 100.0 \\
\hline & & & $\mathrm{U}-235$ & 100.0 \\
\hline & & & U-238 & 100.0 \\
\hline
\end{tabular}


Table 14. FFCA Analytical Completeness Summary-Air Sampler Operation (continued)

\begin{tabular}{|c|c|c|c|c|}
\hline Site \# & Site Name & $\%$ Run & Analysis & $\begin{array}{l}\% \text { Analytical } \\
\text { Completeness }\end{array}$ \\
\hline \multirow[t]{8}{*}{12} & Royal Crest Trailer Court & 98.1 & & \\
\hline & & & Am-241 & 100.0 \\
\hline & & & H-3 & 100.0 \\
\hline & & & $\mathrm{Pu}-238$ & 100.0 \\
\hline & & & $\mathrm{Pu}-239$ & 100.0 \\
\hline & & & $\mathrm{U}-234$ & 100.0 \\
\hline & & & U-235 & 100.0 \\
\hline & & & U-238 & 100.0 \\
\hline \multirow[t]{8}{*}{13} & Rocket Park & 99.8 & & \\
\hline & & & Am-241 & 100.0 \\
\hline & & & $\mathrm{H}-3$ & 100.0 \\
\hline & & & $\mathrm{Pu}-238$ & 100.0 \\
\hline & & & $\mathrm{Pu}-239$ & 100.0 \\
\hline & & & $\mathrm{U}-234$ & 100.0 \\
\hline & & & U-235 & 100.0 \\
\hline & & & U-238 & 100.0 \\
\hline \multirow[t]{8}{*}{14} & Pajarito Acres & 100.0 & & \\
\hline & & & Am-241 & 100.0 \\
\hline & & & H-3 & 100.0 \\
\hline & & & $\mathrm{Pu}-238$ & 100.0 \\
\hline & & & $\mathrm{Pu}-239$ & 100.0 \\
\hline & & & $\mathrm{U}-234$ & 100.0 \\
\hline & & & U-235 & 100.0 \\
\hline & & & U-238 & 100.0 \\
\hline \multirow[t]{8}{*}{15} & White Rock Fire Station & 99.6 & & \\
\hline & & & Am-241 & 100.0 \\
\hline & & & $\mathrm{H}-3$ & 100.0 \\
\hline & & & $\mathrm{Pu}-238$ & 100.0 \\
\hline & & & $\mathrm{Pu}-239$ & 100.0 \\
\hline & & & $\mathrm{U}-234$ & 100.0 \\
\hline & & & U-235 & 100.0 \\
\hline & & & U-238 & 100.0 \\
\hline \multirow[t]{8}{*}{16} & White Rock Nazarene Church & 100.0 & & \\
\hline & & & Am-241 & 100.0 \\
\hline & & & $\mathrm{H}-3$ & 100.0 \\
\hline & & & $\mathrm{Pu}-238$ & 100.0 \\
\hline & & & $\mathrm{Pu}-239$ & 100.0 \\
\hline & & & $\mathrm{U}-234$ & 100.0 \\
\hline & & & U-235 & 100.0 \\
\hline & & & U-238 & 100.0 \\
\hline \multirow[t]{8}{*}{20} & TA-21 Area B & 98.0 & & \\
\hline & & & Am-241 & 100.0 \\
\hline & & & $\mathrm{H}-3$ & 100.0 \\
\hline & & & $\mathrm{Pu}-238$ & 100.0 \\
\hline & & & $\mathrm{Pu}-239$ & 100.0 \\
\hline & & & $\mathrm{U}-234$ & 100.0 \\
\hline & & & $\mathrm{U}-235$ & 100.0 \\
\hline & & & $\mathrm{U}-238$ & 100.0 \\
\hline
\end{tabular}


Table 14. FFCA Analytical Completeness Summary-Air Sampler Operation (continued)

\begin{tabular}{|c|c|c|c|c|}
\hline Site \# & Site Name & $\%$ Run & Analysis & $\begin{array}{l}\% \text { Analytical } \\
\text { Completeness }\end{array}$ \\
\hline \multirow[t]{8}{*}{32} & County Landfill (TA-48) & 99.8 & & \\
\hline & & & Am-241 & 100.0 \\
\hline & & & $\mathrm{H}-3$ & 100.0 \\
\hline & & & $\mathrm{Pu}-238$ & 100.0 \\
\hline & & & $\mathrm{Pu}-239$ & 100.0 \\
\hline & & & U-234 & 100.0 \\
\hline & & & $\mathrm{U}-235$ & 100.0 \\
\hline & & & $\mathrm{U}-238$ & 100.0 \\
\hline \multirow[t]{8}{*}{60} & LA Canyon & 100.1 & & \\
\hline & & & Am-241 & 100.0 \\
\hline & & & H-3 & 100.0 \\
\hline & & & $\mathrm{Pu}-238$ & 100.0 \\
\hline & & & $\mathrm{Pu}-239$ & 100.0 \\
\hline & & & U-234 & 100.0 \\
\hline & & & $\mathrm{U}-235$ & 100.0 \\
\hline & & & U-238 & 100.0 \\
\hline \multirow[t]{8}{*}{61} & LA Hospital & 100.3 & & \\
\hline & & & Am-241 & 100.0 \\
\hline & & & $\mathrm{H}-3$ & 100.0 \\
\hline & & & $\mathrm{Pu}-238$ & 100.0 \\
\hline & & & $\mathrm{Pu}-239$ & 100.0 \\
\hline & & & $\mathrm{U}-234$ & 100.0 \\
\hline & & & $\mathrm{U}-235$ & 100.0 \\
\hline & & & U-238 & 100.0 \\
\hline \multirow[t]{8}{*}{62} & Crossroads Bible Church & 100.3 & & \\
\hline & & & Am-241 & 100.0 \\
\hline & & & H-3 & 100.0 \\
\hline & & & $\mathrm{Pu}-238$ & 100.0 \\
\hline & & & $\mathrm{Pu}-239$ & 100.0 \\
\hline & & & $\mathrm{U}-234$ & 100.0 \\
\hline & & & U-235 & 100.0 \\
\hline & & & $\mathrm{U}-238$ & 100.0 \\
\hline \multirow[t]{8}{*}{63} & Monte Rey South & 100.0 & & \\
\hline & & & Am-241 & 100.0 \\
\hline & & & $\mathrm{H}-3$ & 100.0 \\
\hline & & & $\mathrm{Pu}-238$ & 100.0 \\
\hline & & & $\mathrm{Pu}-239$ & 100.0 \\
\hline & & & U-234 & 100.0 \\
\hline & & & U-235 & 100.0 \\
\hline & & & U-238 & 100.0 \\
\hline
\end{tabular}


Table 15. LANSCE Monthly Assessments and Summary

\begin{tabular}{|c|c|c|}
\hline Description & ESIDNUM & $\begin{array}{c}\text { Dose at East Gate } \\
\text { Receptor }\end{array}$ \\
\hline LANSCE Stack-January & 53000303 & $2.47 \mathrm{E}-04$ \\
\hline LANSCE Stack-February & 53000303 & $4.40 \mathrm{E}-06$ \\
\hline LANSCE Stack-May & 53000303 & 2.91E-04 \\
\hline LANSCE Stack-August & 53000303 & $8.41 \mathrm{E}-06$ \\
\hline LANSCE Stack-September & 53000303 & $3.58 \mathrm{E}-05$ \\
\hline LANSCE Stack-October & 53000303 & $2.87 \mathrm{E}-05$ \\
\hline LANSCE Stack-November & 53000303 & $1.18 \mathrm{E}-05$ \\
\hline LANSCE Stack-December & 53000303 & $1.46 \mathrm{E}-05$ \\
\hline LANSCE Stack-PVAP & 53000303 & 7.57E-05 \\
\hline LANSCE Stack-January & 53000702 & 4.14E-02 \\
\hline LANSCE Stack-February & 53000702 & $6.62 \mathrm{E}-05$ \\
\hline LANSCE Stack-May & 53000702 & $1.69 \mathrm{E}-02$ \\
\hline LANSCE Stack-June & 53000702 & $5.23 \mathrm{E}-03$ \\
\hline LANSCE Stack-August & 53000702 & 8.66E-03 \\
\hline LANSCE Stack-July & 53000702 & $6.75 \mathrm{E}-03$ \\
\hline LANSCE Stack-September & 53000702 & $1.01 \mathrm{E}-02$ \\
\hline LANSCE Stack-October & 53000702 & $2.95 \mathrm{E}-03$ \\
\hline LANSCE Stack-November & 53000702 & $3.19 \mathrm{E}-03$ \\
\hline LANSCE Stack-December & 53000702 & $1.86 \mathrm{E}-03$ \\
\hline LANSCE Stack-PVAP ${ }^{*}$ & 53000702 & 4.84E-05 \\
\hline LANSCE Non-CAP88 Radionuclides ${ }^{*}$ & 53000702 & $2.90 \mathrm{E}-05$ \\
\hline LANSCE Fugitive Emissions ${ }^{*}$ & 53000303 & $1.31 \mathrm{E}-02$ \\
\hline \multicolumn{2}{|l|}{ LANSCE Summary } & 1.11E-01 \\
\hline
\end{tabular}

*Annual Value 
Table 16. 40-61.92 Effective Dose Equivalent at Selected Public Locations

\begin{tabular}{|c|c|c|c|c|c|c|c|}
\hline & & & & Nearest AIRNI & ion & & \\
\hline & Location & Easting & Northing & Sampler Name & \# & $\begin{array}{l}\text { Selected } \\
\text { By }\end{array}$ & $\begin{array}{l}\text { LANL- Wide } \\
\text { EDE* }^{*}\end{array}$ \\
\hline 1 & Los Alamos High School & $1,620,570$ & $1,777,805$ & LA Hospital & 61 & $\mathrm{CAB}^{\dagger}$ & $5.74 \mathrm{E}-02$ \\
\hline 2 & Los Alamos Middle School & $1,626,621$ & $1,780,872$ & Barranca School $^{\ddagger}$ & 04 & $\mathrm{CAB}$ & $2.20 \mathrm{E}-02$ \\
\hline 3 & White Rock Pinon School & $1,651,290$ & $1,754,437$ & Rocket Park & 13 & $\mathrm{CAB}$ & $5.96 \mathrm{E}-02$ \\
\hline 4 & Tsankawi Visitor Center & $1,648,105$ & $1,758,380$ & Well PM-1 & 11 & $\mathrm{CAB}$ & $3.76 \mathrm{E}-02$ \\
\hline 5 & East Road Condos & $1,628,580$ & $1,775,750$ & Cross. Bible Church & 62 & $\mathrm{CAB}$ & $2.98 \mathrm{E}-02$ \\
\hline 6 & Royal Crest Trailer Court - West & $1,624,256$ & $1,773,065$ & Royal Crest Tlr. Crt. & 12 & CAB & $4.13 \mathrm{E}-02$ \\
\hline 7 & 2470 East Gate (NNE sector) & $1,638,825$ & $1,774,097$ & East Gate & 10 & LANL & $1.87 \mathrm{E}-01$ \\
\hline 8 & County Landfill Office & $1,620,569$ & $1,774,763$ & County Landfill & 32 & LANL & $2.10 \mathrm{E}-01$ \\
\hline 9 & Los Alamos Shell & $1,623,892$ & $1,775,889$ & Shell Station & 07 & LANL & $1.29 \mathrm{E}-01$ \\
\hline 10 & Los Alamos Airport & $1,632,902$ & $1,776,247$ & Los Alamos Airport & 09 & LANL & $6.98 \mathrm{E}-02$ \\
\hline 11 & Residence on Nambe Loop & $1,621,568$ & $1,776,046$ & TA-21 Area B & 20 & LANL & $6.94 \mathrm{E}-02$ \\
\hline 12 & Los Alamos Hospital & $1,619,848$ & $1,776,089$ & LA Hospital & 61 & LANL & $6.32 \mathrm{E}-02$ \\
\hline 13 & White Rock Fire Station & $1,653,579$ & $1,756,630$ & WR Fire Station & 15 & LANL & $6.32 \mathrm{E}-02$ \\
\hline 14 & Business on Trinity Drive & $1,626,228$ & $1,775,088$ & LA McDonald's & 08 & LANL & 4.19E-02 \\
\hline 15 & Bandelier Fire Lookout & $1,635,700$ & $1,739,005$ & Bandelier ${ }^{\ddagger}$ & 17 & LANL & $6.49 \mathrm{E}-02$ \\
\hline 16 & Residence on Monte Rey South & $1,647,976$ & $1,750,376$ & Monte Rey South & 63 & LANL & $4.43 \mathrm{E}-02$ \\
\hline 17 & Ponderosa Campground & $1,608,575$ & $1,758,460$ & TA-49 & 26 & LANL & $4.03 \mathrm{E}-02$ \\
\hline 18 & Los Alamos Ice Rink & $1,617,852$ & $1,775,692$ & LA Canyon & 61 & LANL & $3.71 \mathrm{E}-02$ \\
\hline 19 & Residence on Fairway & $1,618,602$ & $1,776,052$ & $48^{\text {th }}$ Street & 06 & LANL & $2.72 \mathrm{E}-02$ \\
\hline 20 & San Ildefonso Pueblo & $1,678,656$ & $1,780,236$ & San Ildefonso & 41 & $\mathrm{CAB}$ & $5.57 \mathrm{E}-02$ \\
\hline 21 & Santa Clara Pueblo & $1,688,500$ & $1,808,360$ & Espanola $^{\ddagger}$ & 01 & $\mathrm{CAB}$ & $4.44 \mathrm{E}-02$ \\
\hline 22 & Abiquiu & $1,620,400$ & $1,894,600$ & Espanola $^{\ddagger}$ & 01 & CAB & $4.38 \mathrm{E}-02$ \\
\hline 23 & Residence at East Gate (N sector) & $1,638,616$ & $1,774,231$ & East Gate & 10 & LANL & $1.54 \mathrm{E}-01$ \\
\hline 24 & Business at East Gate (NE sector) & $1,640,230$ & $1,774,090$ & East Gate & 10 & LANL & $1.40 \mathrm{E}-01$ \\
\hline 25 & Royal Crest Trailer Court - East & $1,625,778$ & $1,772,955$ & Royal Crest Trl. Crt. & 12 & LANL & $4.15 \mathrm{E}-02$ \\
\hline
\end{tabular}

*Note: To allow for more meaningful comparisons, these doses do not include the estimated contribution from unmonitored point sources.

'Citizens' Advisory Board

${ }^{\ddagger}$ Note: These samplers are not part of the regular NESHAP compliance network for LANL. 
Table 17. 40-61.92 Highest Effective Dose Equivalent Summary

\begin{tabular}{|c|c|c|c|c|}
\hline ESIDNUM & Description & $\begin{array}{l}\text { Dose for Release } \\
\text { Site Receptor }\end{array}$ & $\begin{array}{l}\text { Dose at LANL } \\
\text { Receptor }\end{array}$ & $\begin{array}{c}\text { Dose at East Gate } \\
\text { Receptor }\end{array}$ \\
\hline 03002914 & CMR Stack & $1.59 \mathrm{E}-06$ & $1.59 \mathrm{E}-06$ & $1.64 \mathrm{E}-07$ \\
\hline 03002915 & CMR Stack & $2.52 \mathrm{E}-06$ & $2.52 \mathrm{E}-06$ & $3.74 \mathrm{E}-07$ \\
\hline 03002919 & CMR Stack & $2.99 \mathrm{E}-03$ & $2.99 \mathrm{E}-03$ & $4.55 \mathrm{E}-04$ \\
\hline 03002920 & CMR Stack & $1.10 \mathrm{E}-04$ & $1.10 \mathrm{E}-04$ & $1.50 \mathrm{E}-05$ \\
\hline 03002923 & CMR Stack & $1.60 \mathrm{E}-04$ & $1.60 \mathrm{E}-04$ & $2.49 \mathrm{E}-05$ \\
\hline 03002924 & CMR Stack & $1.95 \mathrm{E}-04$ & $1.95 \mathrm{E}-04$ & $2.75 \mathrm{E}-05$ \\
\hline 03002928 & CMR Stack & 4.81E-06 & 4.81E-06 & $8.26 \mathrm{E}-07$ \\
\hline 03002929 & CMR Stack & 3.84E-05 & 3.84E-05 & $6.39 \mathrm{E}-06$ \\
\hline 03002932 & CMR Stack & $0.00 \mathrm{E}+00$ & $0.00 \mathrm{E}+00$ & $0.00 \mathrm{E}+00$ \\
\hline 03002933 & CMR Stack & $8.56 \mathrm{E}-07$ & $8.56 \mathrm{E}-07$ & $1.27 \mathrm{E}-07$ \\
\hline 03002937 & CMR Stack & 4.62E-08 & 4.62E-08 & 5.32E-09 \\
\hline 03002944 & CMR Stack & $1.14 \mathrm{E}-06$ & $1.14 \mathrm{E}-06$ & $1.77 \mathrm{E}-07$ \\
\hline 03002945 & CMR Stack & $0.00 \mathrm{E}+00$ & $0.00 \mathrm{E}+00$ & $0.00 \mathrm{E}+00$ \\
\hline 03002946 & CMR Stack & $9.06 \mathrm{E}-07$ & $9.06 \mathrm{E}-07$ & $1.33 \mathrm{E}-07$ \\
\hline 03003501 & Press Building Stack & $1.42 \mathrm{E}-04$ & $1.42 \mathrm{E}-04$ & $1.25 \mathrm{E}-05$ \\
\hline 03010222 & Shops Addition Stack & 2.63E-05 & $2.63 \mathrm{E}-05$ & $2.95 \mathrm{E}-06$ \\
\hline 16020504 & WETF Stack & $6.35 \mathrm{E}-03$ & $1.34 \mathrm{E}-03$ & 7.60E-04 \\
\hline 18000001 & TA-18 Diffuse & $2.85 \mathrm{E}-05$ & $1.47 \mathrm{E}-06$ & $2.85 \mathrm{E}-05$ \\
\hline 21015505 & TSTA Stack & $2.29 \mathrm{E}-03$ & 3.04E-04 & $1.79 \mathrm{E}-03$ \\
\hline 21020901 & TSFF Stack & $1.64 \mathrm{E}-02$ & $1.85 \mathrm{E}-03$ & $1.33 \mathrm{E}-02$ \\
\hline 33008606 & HP-Site Stack & $2.08 \mathrm{E}-02$ & $1.74 \mathrm{E}-03$ & $3.68 \mathrm{E}-03$ \\
\hline 41000417 & W-Site Stack & $1.62 \mathrm{E}-03$ & $1.15 \mathrm{E}-04$ & $1.93 \mathrm{E}-04$ \\
\hline 48000107 & $\begin{array}{l}\text { Radiochemistry Stack/Non-CAP88 } \\
\text { Radionuclides }\end{array}$ & $9.40 \mathrm{E}-03$ & 8.73E-04 & $9.28 \mathrm{E}-04$ \\
\hline 48000154 & Radiochemistry Stack & $0.00 \mathrm{E}+00$ & $0.00 \mathrm{E}+00$ & $0.00 \mathrm{E}+00$ \\
\hline 48000160 & Radiochemistry Stack & 7.99E-08 & 7.71E-09 & 7.70E-09 \\
\hline 48000160 & $\begin{array}{l}\text { Radiochemistry Stack/Non-CAP88 } \\
\text { Radionuclides }\end{array}$ & $2.22 \mathrm{E}-04$ & $2.04 \mathrm{E}-05$ & 2.07E-05 \\
\hline 50000102 & Waste Management Stack & 2.07E-05 & 2.23E-06 & 6.61E-06 \\
\hline 50003701 & Waste Management Stack & 7.37E-07 & $8.52 \mathrm{E}-08$ & $1.99 \mathrm{E}-07$ \\
\hline 50006903 & Waste Management Stack & $1.08 \mathrm{E}-08$ & 1.22E-09 & $2.56 \mathrm{E}-09$ \\
\hline 53000303 & LANSCE-Annual & 7.96E-04 & $1.22 \mathrm{E}-05$ & $7.96 \mathrm{E}-04$ \\
\hline 530003sy & LANSCE Fugitive-Switch Yard & $1.31 \mathrm{E}-02$ & $3.18 \mathrm{E}-05$ & $1.31 \mathrm{E}-02$ \\
\hline
\end{tabular}


Table 17. 61.92 Highest Effective Dose Equivalent Summary (continued)

\begin{tabular}{llccc} 
ESIDNUM & \multicolumn{1}{c}{ Description } & $\begin{array}{c}\text { Dose for Release } \\
\text { Site Receptor }\end{array}$ & $\begin{array}{c}\text { Dose at LANL } \\
\text { Receptor }\end{array}$ & $\begin{array}{c}\text { Dose at East Gate } \\
\text { Receptor }\end{array}$ \\
\hline 53000702 & LANSCE-Annual & $1.02 \mathrm{E}-01$ & $4.16 \mathrm{E}-04$ & $1.02 \mathrm{E}-01$ \\
53000702 & LANSCE Stack/Non-CAP88 & $2.90 \mathrm{E}-05$ & $6.14 \mathrm{E}-07$ & $2.90 \mathrm{E}-05$ \\
& Radionuclides & & & \\
55000415 & Plutonium Facility Stack & $2.37 \mathrm{E}-05$ & $2.13 \mathrm{E}-06$ & $3.72 \mathrm{E}-06$ \\
55000416 & Plutonium Facility Stack & $1.07 \mathrm{E}-04$ & $1.25 \mathrm{E}-05$ & $2.29 \mathrm{E}-05$ \\
99000000 & Unmonitored Stacks-Gross & $1.10 \mathrm{E}-01$ & $1.10 \mathrm{E}-01$ & $1.10 \mathrm{E}-01$ \\
99000010 & Air-Sampler Net Dose & $2.00 \mathrm{E}-01$ & $2.00 \mathrm{E}-01$ & $5.00 \mathrm{E}-02$ \\
\hline
\end{tabular}


1999 LANL Radionuclide Air Emissions Report

\section{References}

1. U.S. Department of Energy, "Site-Wide Environmental Impact Statement for Continued Operation of the Los Alamos National Laboratory,” Vol. Summary, DOE/EIS - 0238, Albuquerque NM, January 1999.

2. K. W. Jacobson, S. Duffy, and K. Kowalewsky, "Population and Agricultural Data Arrays for the Los Alamos National Laboratory," Los Alamos National Laboratory report LA-13469-MS (1998).

3. S. D. Terp, “1999 Radioactive Materials Usage Survey for Point Sources,” Los Alamos National Laboratory report LA-UR 00-2338 (2000).

4. Los Alamos National Laboratory, "Performance Requirements for Air Quality,” Air Quality Group Laboratory Implementation Requirement, LPR 404-10-00.0 (1998).

5. U.S. Environmental Protection Agency, Federal Register, Vol. 60, No. 107 (June 5, 1995).

6. U.S. Environmental Protection Agency, "The Clean Air Act Assessment Package-1988 (CAP-88): A Dose and Risk Assessment Methodology for Radionuclide Emissions to Air," Vol. 1: User's Manual, EPA/Washington D.C. (1990).

7. Radiation Shielding Information Center, “CAP-88 Clean Air Act Assessment Package,” Oak Ridge National Laboratory, Tennessee (1990).

8. U.S. Environmental Protection Agency, "National Emission Standards for Emissions of Radionuclides other than Radon from Department of Energy Facilities," Code of Federal Regulations, Title 40, Part 61.90, Subpart H (1989).

9. Keith F. Eckerman, Anthony B. Wolbarst, and Allan C.B. Richardson, Federal Guidance Report No. 11, "Limiting Values of Radionuclide Intake and Air Concentration And Dose Conversion Factors for Inhalation, Submersion, and Ingestion," Office of Radiation Programs, U.S. Environmental Protection Agency, Washington D.C., 1988.

10. K.F. Eckerman and J.C. Ryman, Federal Guidance Report No. 12, "External Exposures to Radionuclides in Air, Water, and Soil Exposure-to-Dose Coefficients for General Application,” U.S. Environmental Protection Agency, Washington, D.C., 1993.

11. Keith W. Jacobson, e-mail to Mr. George P. Brozowski, U.S. Environmental Protection Agency Region VI, March 18, 1999.

12. Bart Eklund, "Measurements of Emission Fluxes from Technical Area 53, Areas G and L," Radian Corporation report, Austin, Texas (1995).

13. Los Alamos National Laboratory, "Performance Assessment and Composite Analysis for Los Alamos National Laboratory Materials Disposal Area G,” Los Alamos National Laboratory report LA-UR9785 (1997). 


\subsection{4(b)(9) Certification}

I certify under penalty of law that I have personally examined and am familiar with the information submitted herein and based on my inquiry of those individuals immediately responsible for obtaining the information, I believe that the submitted information is true, accurate, and complete. I am aware that there are significant penalties for submitting false information including the possibility of fine and imprisonment (See, 18 USC., 001).

Signature:
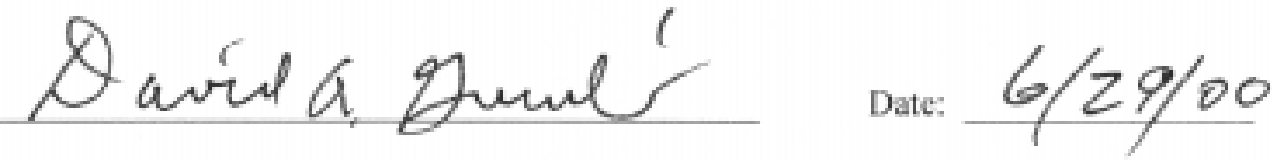

David A. Gurulé, P.E., Ohwner Area Manager, Los Alamos Area Office

U.S. Department of Energy
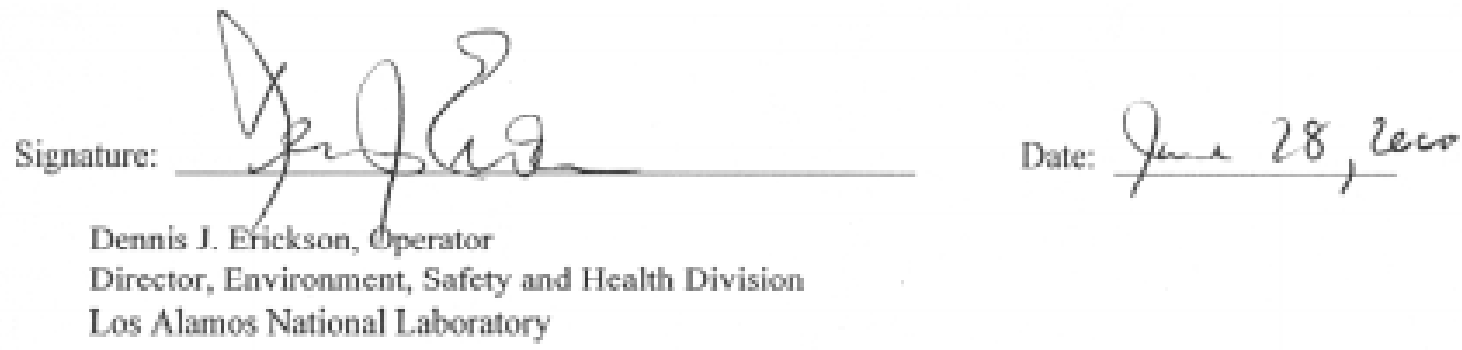
1998 LANL Radionuclide Emissions Report Errata as noted by J.C. Lochamy and K. W. Jacobson

Table 9:

The records beginning with "53DIFFUS" should not have been included on page 5 of Table 9 , as they were correctly listed in Table 10.

Table 12:

The "rounded total" column in Table 12 included tritium doses from both the old and new methods for calculating tritium concentrations. Tritium doses for only the new method should have been included.

Table 16:

The dose for the "Unmonitored Stacks-gross" source is listed as 2.71e-2 on page 2 of Table 16, it should have read 2.71e-1.

certification statement:

The last word in the first paragraph of the Certification Statement should read "1001", not "001" 

This report has been reproduced directly from the best available copy. It is available electronically on the Web (http://www.doe.gov/bridge).

Copies are available for sale to U.S. Department of Energy employees and contractors from-

Office of Scientific and Technical Information

P.O. Box 62

Oak Ridge, TN 37831

(423) $576-8401$

Copies are available for sale to the public from-

National Technical Information Service

U.S. Department of Commerce

5285 Port Royal Road

Springfield, VA 22616

(800) 553-6847 


\section{Los Alamos \\ NATIONAL LABORATORY \\ Los Alamos, New Mexico 87545}

